\title{
Covid-19 and Corporate Tax Avoidance: Measuring Long- run Tax Burdens as an Alternative Bailout Test
}

\section{Subagio Efendi ${ }^{\alpha}$}

\section{*Email: subagio.efendi@uts.edu.au}

a Directorate General of Taxes, Ministry of Finance of Indonesia Jl. Jend. Gatot Subroto Kav. 40-42, Jakarta, Indonesia Accounting Discipline Group, University of Technology Sydney, Business School 14-28 Ultimo Road, NSW 2007, Australia

Riwayat artikel:

- Diterima 17 September 2020

- Direvisi 21 Oktober 2020

- Disetujui 15 Desember 2020

- Tersedia online 8 Juli 2021

\begin{abstract}
This study extends Covid-19 bailout conditionality research by examining and nominating Long-run Effective Tax Rate as the better corporate tax avoidance measure for excluding tax evader firms from the extensive Covid-19 financial aid programs. Analysing confidential tax returns of 4,752 largest firms in Indonesia over 2009 to 2017 periods, this study finds 18.12 per cent of total sample firms are able to retain their Long-run Effective Tax Rate below 10 per cent, which indicates continual tax avoidance activities by these firms during observation periods. Moreover, applying univariate and multivariate Ordinary Least Squares and Panel Data estimations, this study reveals, relative to other tax avoidance measures, Lagged Cash Effective Tax Rate presents the most consistent reliability in predicting long-run income tax burdens. Thus, this study asserts, in the conditions of computing Long-run Effective Tax Rate is costly and impractical (i.e., because of data unavailability), tax authorities and policymakers can directly analyse firms' Lagged Cash Effective Tax Rate to gauge their long-run tax burdens and tax compliance behaviours before the economic downturn.
\end{abstract}

Keywords:

covid-19; tax avoidance measure; bailout verification; long-run tax burdens; tax return

JEL Classification :

M41; M48; G32; G38; H25; H26 


\section{INTRODUCTION}

Corporate tax avoidance has been the central theme of recent global policy reforms following large shreds of evidence on the magnitude of revenue losses caused by various tax avoidance schemes operated by multinational corporations. ${ }^{1}$ Apple, the most profitable company in the US fortune 500 , for instance, can maintain a low effective foreign tax rate of 5.8 per cent and avoid 78.5 billion US dollars of US taxes during 2008 and 2015 by shifting a substantial portion of its profit to three 'non-resident' Irish subsidiaries (ITEP, 2017a). Similarly, Nike is able to maintain 18.6 per cent effective tax rate out of more than 10 billion US dollars of profit between 2008 and 2015 by, under the Dutch Tax Authority's approval, shifting a significant portion of its royalty income to a Bermudan subsidiary which held legal ownership of its valuable intellectual properties (ITEP, 2017b). ${ }^{2}$ Additionally, UNCTAD (2015) estimated the fiscal resource leakage suffered by developing countries as a result of large multinationals' tax avoidance schemes is more than 100 billion US dollars every year. Furthermore, Covid-19 pandemic has exacerbated the impact of tax avoidance on the state's budget by limiting its ability to supply the necessary stimulus packages to jumpstart the economy (Laffitte, Martin, Parenti, Souillard, \& Toubal, 2020).

The Covid-19 pandemic has shifted fiscal authorities' macroeconomic policy priorities to preserving jobs and households' purchasing power, averting rampant corporate bankruptcies, increasing health facilities' capacity, and sustaining a stable financial system (Collier, Pirlot, \& Vella, 2020; Gourinchas, 2020). However, the enduring corporate tax avoidance schemes executed by large multinationals, particularly in the technology sectors, have constrained the authority's capability to offer various tax relief and incentive programs. Furthermore, the far-reaching stimulus programs financed by the current, and future, taxpayers' money has received considerable public scrutinies when they are, also, enjoyed by tax evaders that have been avoiding their fair share of tax payments before the economic downturn (Giuliani, 2020; Laffitte et al., 2020; Tax Justice Network, 2020). ${ }^{3}$

Responding to these crucial accountability and fairness issues on the use of public budgets, several leading European economies (i.e., Denmark, France, Poland, Belgium, Sweden, Austria) have initiated bold policies in excluding firms registered or having subsidiaries in tax havens from their generous state-aid programs. ${ }^{4}$ The European Commission further supports these policies, which underlined tax compliance as a foundational prerequisite in receiving financial aid, as suitable additional measures to prevent fraud, tax evasion, or aggressive tax avoidance within the framework of the European Union's Covid-19 state aid regulations (Lind, 2020). Moreover, inproviding more comprehensive bailout criteria for fiscal authorities, the Tax Justice Network (2020) complements the singular tax haven restriction with prior participation in illicit financialflows scandals (e.g., illegal state aids, Panama Papers, LuxLeaks); disclosure of group-wide taxaccounts; beneficial ownership and country-by-country reports; and proper implementation ofsafeguard measures to protect employees and prevent shareholders' extractions of state-aids (e.g., dividend distributions, bonuses, share buy-backs) ${ }^{5}$

\footnotetext{
${ }^{1}$ Some influential revelations include the Luxembourg Leaks (ICIJ, 2014), the Panama Papers (ICIJ, 2016), the Paradise Papers (ICIJ, 2017), and the Mauritius Leaks (ICIJ, 2019).

${ }^{2}$ Further, since 2015, Nike transferred the ownership of its intellectual properties to a Dutch-hybrid mismatch entity, which lowers the firm's worldwide effective tax rate to 13.2 per cent (ITEP, 2017b).

${ }^{3}$ The rising public inquiries on corporate tax avoidance practices are argued to be part of a broad ideological shift towards distributive justice (i.e., increasing concern on economic inequality and the government's distributive policies) caused by the Covid-19 crisis (Giuliani, 2020).

${ }^{4}$ Denmark and Sweden exclude firms registered in countries or jurisdictions listed in the EU blacklist of noncooperative tax jurisdictions from their respective state-aid programs. Additionally, Poland incorporates a 'redomicile' provision that allows tax haven firms to relocate their businesses within a specific time frame to be eligible for the stimulus. Countries or jurisdictions listed in the EU's blacklist are American Samoa, Cayman Islands, Fiji, Guam, Oman, Palau, Panama, Seychelles, Trinidad, Tobago, and Vanuatu (Lind, 2020).

${ }^{5}$ See Tax Justice Network (2020, p. 5) for detailed recommendations of qualifying criteria and condition for Covid-19 bailouts.
} 
Regardless of the profound objectives, the simplistic, and arbitrary, sole criteria of tax avoidance (i.e., registered and operated in a tax haven) have created some administrative problems for tax authorities caused by the ambiguous definition of registration, violation of 'freedom-ofcontract' principle by assuming every company located in a tax haven is utilised to avoid taxeswhich not always accurate since they may have other bona fide reasons of existence, and legal conflict with several applicable international treaties (e.g., double tax conventions) with these tax havens (Lind, 2020; Tax Justice Network, 2020). These impediments have stimulated a rising demand for a better measure of corporate tax avoidance in improving the accountability and lawfulness of current state-aid programs. Correspondingly, Tax Justice Network (2020) proposed that, other than tax avoidance, the bailout restriction should adopt broader transparency and governance criteria, especially corruption, money laundering, and unethical business conducts. Nevertheless, considering the aid programs' immediate nature, selecting more restriction criteria may lessen the programs' effectiveness and administratively impractical.

This exploratory study aims to examine and nominate firms' long-run tax burdens (proxied by Long-run Cash Effective Tax Rate/Long-run ETR) as a better criterion of tax avoidance using a panel of confidential corporate income tax return data of large firms and permanent establishments operating in Indonesia. ${ }^{6}$ Earlier studies (e.g., Dyreng, Hanlon, \& Maydew, 2008; Hanlon \& Heitzman, 2010; Hoopes, Mescall, \& Pittman, 2012) assert that, compared to employing an annual Cash ETR, aggregating Cash ETR over medium and long periods (i.e., Cash ETR5 and Long-run ETR) is able to mitigate transitory shocks of the proxy which improve its reliability in predicting corporate tax avoidance. Thus, Long-run ETR is capable in reflecting any form of income tax reductions relative to pre-tax accounting income, both from existing tax avoidance schemes and preferential treatments provided by the tax law (Dyreng, Hanlon, Maydew, \& Thornock, 2017), and, hence, reveals firms' tax compliance behaviours before the pandemic.

This study is descriptive in nature as its focus on evaluating the reliability of existing tax avoidance measures in reflecting long-run tax burdens rather than testing a specific hypothesis about associations of Covid-19 pandemic and firms' long-run tax avoidance, leaving that for future research. Moreover, this study extends the validation methods proposed by Dyreng et al. (2008) through testing nearly all tax avoidance measures (including a tax authority's internal risk assessment) employed in the literature. Recall that not all tax avoidance measures are appropriate in estimating firms' long-run tax burdens (Dyreng et al., 2008), the findings are beneficial in guiding future research investigating determinants and consequences of long-run tax avoidance. Furthermore, the findings also have important policy implications considering the escalating concerns of tax authorities in inferring the nature of corporate tax compliance as an essential prerequisite in receiving financial aids.

Analysing an unbalanced sample of 4,752 unique firms (32,120 firm-years) from 2009 to 2017, this study finds the mean (median) of Long-run ETR is 23.52 per cent (25.47 per cent). Furthermore, 18.12 per cent of the total sample firms are able to hold their Long-run ETR below 10 per cent, which indicates continual tax avoidance activities by these firms during this observation period. Moreover, applying univariate and multivariate Ordinary Least Squares (OLS) and Panel Data estimations, this study reveals, relative to other measures, Lagged Cash ETR (Lisowsky, 2010; Lisowsky, Robinson, e Schmidt, 2013) presents the most reliability in predicting long-run income tax burdens. Therefore, thisstudy proposes that tax authorities should refine their tax avoidance criteria by examining variations of firms' Long-run ETR in granting the broad state-aid programs. However, constrained by data availability, computing Long-run ETR may be problematic (e.g., for newly registered firms or in the case of business restructurings). Alternatively, tax authorities can directly employ firms' Lagged Cash ETR to infer their long-run tax burdens and, thus, include this reliable proxy in the bailout verifications.

${ }^{6} \mathrm{~A}$ permanent establishment is a fixed place controlled by a foreign taxpayer to partly or wholly operate its business (OECD, 2017). Typical examples of permanent establishments are branches, representative offices, factories, workshops, mining sites, and construction or installation projects. 
The remainder of this study is organised as follows. The next section reviews existing studies examining corporate tax avoidance. This part is followed by the section that explains the research methodology, data collection, and sample selections. The section that discusses empirical results and sensitivity analysis follows next together with the section that summarises and concludes the study.

\section{LITERATURE REVIEW}

Considering the exploratory and descriptive natures of this study, the main focus of reviewing voluminous existing corporate tax avoidance research is not to develop specific hypothesis and prediction about associations of Covid-19 pandemic and firms' long-run tax avoidance. Instead, it identifies specific corporate tax avoidance measures being employed by these studies in making inferences about determinants and consequences of tax avoidance. The extant literature, because of the limited availability of tax return data, has a long history of reliance on public firms' financial information in constructing specific tax avoidance measures. The measures are primarily designed to estimate firms' effective income tax burdens (i.e., income tax liabilities as a percentage of accounting earnings or cash flows), capital investments' marginal tax rates, implicit taxes effects, the differences between accounting earnings and taxable income (i.e., to capture corporate tax avoidance schemes after controlling the impacts of accounting accruals and earning management), involvement in tax sheltering activities, tax uncertainties, the differences in tax rates across industries or countries/jurisdictions (i.e., to captures incentives of profit shifting and tax arbitrage), and the differences between tax paid and statutory tax liabilities (i.e. to capture taxsubsidies). Frequent examples of the existing tax avoidance measures based on reviewing priorstudies are variations of ETR over the short and long-run periods, Marginal tax rate, ETR differential, Book-tax differences (BTD), Book-tax gap (BTG), Permanent differences, Uncertain tax benefit (UTB) reserve, Tax arbitrage, Tax shelter score, Tax subsidies on equities, tax authorities' audit case selection index, and the residuals of regressing total accounting accruals to BTG or total permanent differences (i.e., Tax shelter/Abnormal BTG, DTAX). ${ }^{7}$

This study initially identifies thirty corporate tax avoidance (aggressiveness) measures from reviewing earlier tax studies. Nevertheless, because of data limitations as well as necessary exclusions of several proxies that have similar theoretical construct and, hence, capture the same underlying tax avoidance components, this study only able to examines the reliability of sixteen measures (i.e., six measures are variants of ETR ratio, five measures are based on book-tax differences, one measure captures implicit income tax burdens, one measure captures tax arbitrage induced by differences in statutory income tax rate across jurisdictions, one measure is a quantitative prediction of tax sheltering likelihood, one measure is a tax authority's internal assessment of tax avoidance risks, and the remaining measure is a residual of an econometric model designed to capture tax aggressiveness behaviours). Table 1 summarises the definitions of existing tax avoidance measures and their relevance to this study. While multiple measures existed, studies argued that Cash ETR, Book (GAAP) ETR, BTD, and UTB reserve are the most frequently used proxies in the literature (Blouin, 2014; Dyreng et al., 2017).

Public financial information-based tax avoidance measures are intuitive and relatively easy to construct. Furthermore, much of the popular media and policymakers' attention to corporate tax compliance relies on ETRs measured from financial statements (Callihan, 1994; Gupta \& Newberry, 1997). Nevertheless, their reliability in predicting long-run tax burdens may be problematic.Omer et al. (1991) found systematic deferred tax liability reporting differences lessen ETRs' reliability in predicting actual income tax burdens. Similarly, Dyreng et al. (2008) document annual Cash ETR's inability in reflecting long-run effective tax burdens, which lower the measure's reliability in predicting firms' long-run tax avoidance behaviours. This study aims to improve the external validity of these findings using novel tax return data.

${ }^{7}$ See Hanlon and Heitzman (2010) for a review of existing tax avoidance measures. Also, see Callihan (1994) for a discussion on alternative measures and applications of ETR. 


\section{RESEARCH METHOD}

In investigating the research question-whether existing tax avoidance measures reflect long-run income tax burdens, this study begins with constructing a proxy of a firm's long-run tax burdens (i.e., Long-run ETR) by dividing nine consecutive years' aggregate tax paid with its corresponding aggregate pre-tax income (as in Dyreng et al., 2008) as equation (1): ${ }^{8}$

$$
\text { LongrunETR }_{i}=\frac{\Sigma_{t=1}^{9} \text { Income tax paid }_{i t}}{\Sigma_{t=1}^{9} \text { Pre-tax } \text { income }_{i t}}
$$

Furthermore, this study partially replicates validating methods employed in Plesko (2003) by assigning Long-run ETR as the primary dependent variable and individual tax avoidance measure as the explanatory variable in the regression model (2):

$$
\text { LongrunETR }_{i}=\alpha+\beta \text { TAM }_{i}+\Sigma \delta_{k} \operatorname{CONTROLS}_{i}+\Sigma \theta_{l} \operatorname{INDUSTRY}_{l}+\varepsilon_{i}
$$

Long-run ETR is a firm's long-run income tax burdens and, the variable of interest, TAM is the individual tax avoidance measure being tested as outlined in Table l. If existing tax avoidance measures are reliable in predicting firms' long-run tax burdens, the regression results of equation (2) need to present a statistically significant coefficient of TAM with $\beta$ materially different from 0 . Conversely, if existing tax avoidance measures are weak proxies of the long-run tax burdens, then the coefficient should be statistically insignificant.

Moreover, to ascertain, in comparison, which existing tax avoidance measures present more information about the long-run income tax burdens, following Lisowsky et al. (2013) and Efendi et al. (2020), this study assigns existing measures which retain a significant association with Longrun ETR in the individual estimation of equation (2) in one regression model and allow them to 'compete'. Thus, this study estimates the regression model (3) after correcting multicollinearity problems caused by cross-correlations among independent variables:

$$
\begin{aligned}
& \text { LongrunETR }_{i}=\alpha+\beta_{1} \text { CashETR }_{i}+\beta_{2} \text { LagETR }_{i}+\beta_{3} \text { GAAPETR }_{i}+\beta_{4} \text { CashflowETR }_{i}+ \\
& \beta_{5} \text { EBITETR }_{i}+\beta_{6} \text { DeferETR }_{i}+\beta_{7} \text { BTD }_{i}+\beta_{8} \text { TotalBTD }_{i}+\beta_{9} \text { BTG }_{i}+\beta_{10} \text { SPREAD }_{i}+ \\
& \beta_{11} \text { TSE }_{i t}+\beta_{12} \text { Shelter }_{i}+\beta_{13} \text { Audit }_{i}+\beta_{14} \text { TemporaryBTD }_{i}+\beta_{15} \text { Arbitrage }_{i}+ \\
& \beta_{16} \text { DTAX }_{i}+\Sigma \delta_{k} \text { CONTROLS }_{i}+\Sigma \theta_{l} \text { INDUSTRY }_{l t}+\varepsilon_{i}
\end{aligned}
$$

The variables of interest are Cash ETR and other fifteen existing tax avoidance measures. Thus, the most reliable tax avoidance measure needs to have a statistically significant coefficient with the highest value of $\beta$.

Control variables for all regression models are various firm characteristics associated with corporate tax avoidance suggested by earlier studies: size (measured as the natural log of total assets) to control for economy of scale and political cost effects as proposed by Zimmerman (1983) and Gupta and Newberry (1997), return on assets (measured as pre-tax income scaled by total assets) to control for firm's profitability as indicated by Gupta and Newberry (1997) and Plesko (2003), leverage (measured as total long-term debts scaled by total assets) to control for firm's incentive in thin capitalisation as indicated by Cheng et al. (2012), foreign operations (measured as foreign income scaled by total assets) to control for firm's international operations as suggested by Rego (2003) and Lisowsky (2010), capital intensity (measured as total non-current assets scaled by total assets) and inventory intensity (measured as inventory scaled by total assets) to control for firm's investment choice as suggested by Gupta and Newberry (1997) and Plesko (2003), fiscal loss (measured as dummy variable coded 1 if firm have fiscal loss compensation and 0 otherwise) and changes in fiscal loss compensation (measured as changes in fiscal loss carry

\footnotetext{
${ }^{8}$ Dyreng et al., (2008), as outlined in Table 1, used ten consecutive years' aggregate tax paid and the corresponding pre-tax income in constructing their measure of long-run tax burdens (i.e., Cash ETR10). However, because of data limitations, the main proxy of long-run tax burdens in this study only comprises of nine consecutive years' aggregate tax paid and the corresponding pre-tax income. This study expects this oneyear data omission in the variable construction will not substantially affect the results.

http://dx.doi.org/10.31685/kek.V4i3.888
} 
-forward scaled by lagged total assets) to control for firm's incentive to reduce income tax burdens as suggested by Rego (2003). Additionally, this study control for industry fixed effects using twodigit of Indonesia's standard industry classification developed by the Central Bureau of Statistics of Indonesia (2015).

Finally, to examine existing tax avoidance measures' sensitivity to the inclusion of control variables, following Plesko (2003) and Efendi et al. (2020), this study estimates regression model (2) using univariate and multivariate OLS methods where all controls are excluded in the univariate analyses. 
TABLE-1: Alternative measures of corporate tax

avoidance

\begin{tabular}{|c|c|}
\hline Measure & Description \\
\hline \multirow[t]{2}{*}{ Cash ETR } & Worldwide cash income tax paid \\
\hline & $\overline{\text { Worldwide total pretax accounting income }}$ \\
\hline \multirow[t]{2}{*}{ Cash ETR3 } & $\sum_{i=1}^{3}$ Worldwide cash income tax paid \\
\hline & $\sum_{i=1}^{3}$ Worldwide total pretax accounting income \\
\hline \multirow[t]{2}{*}{ Cash ETR5 } & $\sum_{i=1}^{5}$ Worldwide cash income tax paid \\
\hline & $\overline{\sum_{i=1}^{5} \text { Worldwide total pretax accounting income }}$ \\
\hline \multirow{2}{*}{$\begin{array}{l}\text { Cash ETR10 } \\
\text { (Long-run ETR) }\end{array}$} & $\sum_{i=1}^{10}$ Worldwide cash income tax paid \\
\hline & $\sum_{l=1}^{10}$ Worldwide total pretax accounting income \\
\hline \multirow[t]{2}{*}{ Lagged Cash ETR } & Worldwide cash income tax paid t-1 $_{1}$ \\
\hline & Worldwide total pretax accounting income t $_{-1}$ \\
\hline \multirow[t]{2}{*}{ Current ETR } & Worldwide current income tax expense \\
\hline & Worldwide total pretax accounting income \\
\hline \multirow[t]{2}{*}{ GAAP ETR } & Worldwide total income tax expense \\
\hline & $\overline{\text { Worldwide total pretax accounting income }}$ \\
\hline
\end{tabular}

Reference(s)
Gupta and Newberry (1997); Dyreng et al.
(2008); Dyreng et al. (2010); Chen et al. (2010);
Hanlon and Heitzman (2010); McGuire et al.
(2012); Badertscher et al. (2013); Huang et al.
(2016); Dyreng et al. (2017).

Hoopes et al. (2012); Blouin (2014).

Dyreng et al. (2008); Rego and Wilson (2012); Huang et al. (2016).

Dyreng et al. (2008); Hanlon and Heitzman (2010); Lisowsky (2010)

Lisowsky (2010); Lisowsky et al. (2013).

Gupta and Newberry (1997); Hanlon and Heitzman (2010); Huang et al. (2016).

Dyreng et al. (2008); Dyreng et al. (2010); Hanlon and Heitzman (2010); Hoopes et al (2012); McGuire et al. (2012); Badertscher et al. (2013); Dyreng et al. (2017).
Excluded from the analysis due to high correlations with the dependent variables.

Yes, as the dependent variable in the sensitivity analysis.

Yes. However, because of insufficient data, the Long-run ETR is constructed using nine years' aggregate tax paid scaled by its corresponding aggregate pretax income.

Yes

Excluded from the analysisbecause the measure provides similar inference with Cash ETR.

Yes 


\begin{tabular}{|c|c|c|c|}
\hline Measure & Description & Reference(s) & Relevant to this study? * \\
\hline ETR Differential & Statutory income tax rate - GAAP ETR & Hanlon and Heitzman (2010). & $\begin{array}{l}\text { Excluded from the analysis } \\
\text { because the measure provides } \\
\text { similar inference with GAAP ETR. }\end{array}$ \\
\hline \multirow[t]{2}{*}{ Cash flow ETR } & Worldwide income tax expense $-\Delta$ Deferred tax & \multirow{2}{*}{$\begin{array}{l}\text { Zimmerman (1983); Hoopes et al. (2012); } \\
\text { Dyreng et al. (2017). }\end{array}$} & \multirow[t]{2}{*}{ Yes } \\
\hline & Net operating cash flows & & \\
\hline EBIT ETR & Current income tax expense & \multirow[t]{2}{*}{ Gupta and Newberry (1997). } & \multirow[t]{2}{*}{ Yes } \\
\hline Deferred ETR & $\begin{array}{l}\text { Earning before interest and taxes } \\
\text { Tax Expense - } \Delta \text { Deferred tax }\end{array}$ & & \\
\hline Global ETR & $\begin{array}{c}\text { Pretax income }-\Delta \text { Deferred tax Statutory income tax rate } \\
(\text { Tax federal }+ \text { Tax foreign })\end{array}$ & Porcano (1986). & Excluded from the analysisbecause \\
\hline & (Worldwide income + Extra + Discount - Subsidiaries $)$ & Manzon and Plesko (2001). & $\begin{array}{l}\text { of data unavailability in the non- } \\
\text { consolidated financial statement. } \\
\text { Excluded from the analysisbecause }\end{array}$ \\
\hline Worldwide ETR & Tax Expense - Deferred Tax & & the measure provides similar \\
\hline RealETR & $\begin{array}{c}\text { Pretax income } \\
\frac{\text { Federal,state, and foreign income taxes paid }}{\text { Real distributable profit }}\end{array}$ & Bernard and Hayn (1986) & $\begin{array}{l}\text { inference with cash ETR. } \\
\text { Excluded from the analysisbecause } \\
\text { of replacement cost-income data } \\
\text { unavailability. }\end{array}$ \\
\hline Book-tax & Pretax income - Taxable income & Mills (1998); Desai and Dharmapala (2006); & Yes \\
\hline Difference & Lagged total assets & McGuire et al. (2012). & \\
\hline $\begin{array}{l}\text { Total Book-tax } \\
\text { Difference }\end{array}$ & $\begin{array}{c}\text { Pretax book income }-((U S C T E+\text { Foreign CTE }) / U S S T R)-\left(N O L_{t}\right. \\
\left.-N O L_{t-1}\right)\end{array}$ & Hanlon and Heitzman (2010). & Yes \\
\hline
\end{tabular}




\begin{tabular}{|c|c|c|c|}
\hline \multirow{3}{*}{\begin{tabular}{l}
\multicolumn{1}{c}{ Measure } \\
Temporary Book- \\
tax Difference
\end{tabular}} & Description & Reference(s) & Relevant to this study? * \\
\hline & Deferred tax expense & \multirow[t]{2}{*}{ Hanlon and Heitzman (2010). } & \multirow[t]{2}{*}{ Yes } \\
\hline & $\overline{\text { Statutory income tax rate }}$ & & \\
\hline Book-tax Gap & $\begin{array}{c}\text { (Pretax income - Deferred tax Statutory income tax rate) } \\
\text { Tax expense - Deferred tax }\end{array}$ & Desai (2003); Desai and Dharmapala (2009). & Yes \\
\hline Permdiff & $\begin{array}{c}\text { (Pretax income }-(\text { Current tax federal } \\
+ \text { Current tax foreign }) / \text { Statutory tax rate }) \\
-(\text { Deferred tax } / \text { Statutory tax rate })\end{array}$ & Frank et al. (2009); Huang et al. (2016). & $\begin{array}{l}\text { Excluded from the analysis } \\
\text { because the measure provides } \\
\text { similar inference with book-tax } \\
\text { gap. }\end{array}$ \\
\hline \multirow[t]{2}{*}{ SPREAD } & Domestic income - ( Current tax expense $)$-Income taxes & Manzon and Plesko (2001). & Yes \\
\hline & $\begin{array}{l}\text { Statutory income tax rate } \\
\text { - Equity in net loss }\end{array}$ & & \\
\hline Tax Arbitrage & $\frac{\text { Foreign tax expense }}{\text { Foreign pretax income }}-$ Statutory income tax rate & Klassen and Laplante (2012). & Yes \\
\hline Tax & Residual from the following regression: & Desai and Dharmapala (2006); Hanlon and & Excluded from the analysis \\
\hline $\begin{array}{l}\text { Shelter/Abnormal } \\
\text { Book-tax Gap }\end{array}$ & $B T G_{/ T A_{i t}}=\beta T A_{i t}+\delta \mu_{i}+\varepsilon_{i t}$ & Heitzman (2010). & $\begin{array}{l}\text { because the measure provides } \\
\text { similar inference with book-tax } \\
\text { differences. }\end{array}$ \\
\hline DTAX & 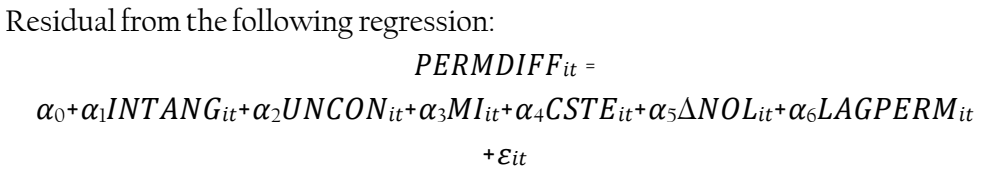 & $\begin{array}{l}\text { Frank et al. (2009); McGuire et al. (2012); Rego } \\
\text { and Wilson (2012); Badertscher et al. (2013); } \\
\text { Kubick and Masli (2016). }\end{array}$ & Yes \\
\hline $\begin{array}{l}\text { Unrecognised } \\
\text { Tax Benefits } \\
\text { Reserve }\end{array}$ & $\begin{array}{l}\text { Disclosed uncertain tax benefits reserve post-FIN } 48 \\
\text { Heitzman, }\end{array}$ & $\begin{array}{l}\text { Hanlon and Heitzman (Hanlon \& } \\
\text { 2010); Lisowsky et al. (2013). }\end{array}$ & $\begin{array}{l}\text { Excluded from the analysisbecause } \\
\text { of different financial accounting } \\
\text { treatment of unrecognised tax } \\
\text { benefits reserve in the US and } \\
\text { Indonesia }\end{array}$ \\
\hline
\end{tabular}




\begin{tabular}{|c|c|c|c|}
\hline Measure & Description & Reference(s) & Relevant to this study? * \\
\hline $\begin{array}{l}\text { Marginal Tax } \\
\text { Rate }\end{array}$ & Simulated marginal income tax rate & Shevlin (1990); Hanlon and Heitzman (2010). & $\begin{array}{l}\text { Excluded from the analysis } \\
\text { because of insufficient data to } \\
\text { construct the variable. }\end{array}$ \\
\hline \multirow{2}{*}{$\begin{array}{l}\text { Tax Subsidy on } \\
\text { Equity }\end{array}$} & (Pretax income $x$ Statutory income tax rate)-Current tax expense & \multirow[t]{2}{*}{ Wilkie (1992); Wilkie and Limberg (1993). } & \multirow[t]{2}{*}{ Yes } \\
\hline & Stockholders'equity & & \\
\hline Tax Shelter Score & $\begin{array}{c}\text { SHELTER }=-4.30+6.63 * \text { BTD }-1.72 * \text { Leverage }+0.66 * \text { Size }+2.26 \\
* R O A+1.62 * \text { ForeignIncome }+1.56 * R \& D\end{array}$ & $\begin{array}{l}\text { Wilson, (2009); Lisowsky, (2010); Rego and } \\
\text { Wilson (2012); Badertscher et al. (2013); Kubick } \\
\text { and Masli (2016). }\end{array}$ & $\begin{array}{l}\text { Yes. However, research and } \\
\text { development expenses are } \\
\text { excluded from the variable } \\
\text { construction since they are not } \\
\text { statistically significant in Table } 5 \text { of } \\
\text { Wilson }(2009 \text { p. } 988) \text {. }\end{array}$ \\
\hline TPRICE & $\begin{aligned} \text { TPRICE }=1.672 & +0.264 * \text { Size }+0.079 * \text { Profit }+0.095 * \text { Leverage } \\
& +0.025 * \text { Intangibles }+0.071 * \text { Multinationality } \\
& +0.006 * \text { Tax Haven }\end{aligned}$ & Richardson et al. (2013); Taylor et al. (2015). & $\begin{array}{l}\text { Excluded from the analysis } \\
\text { because the measure is an indirect } \\
\text { proxy of tax avoidance utilising } \\
\text { related-party transactions. }\end{array}$ \\
\hline \multirow[t]{2}{*}{ Tax Cushion } & Current tax expense - Income tax paid - Tax benefit - $\Delta$ Tax payable & \multirow[t]{2}{*}{ Blouin and Tuna (2007). } & \multirow{2}{*}{$\begin{array}{l}\text { Excluded from the analysisbecause } \\
\text { of stock option's tax benefits data } \\
\text { unavailability. }\end{array}$} \\
\hline & Lagged total assets & & \\
\hline $\begin{array}{l}\text { Tax authority's } \\
\text { audit case } \\
\text { selection index }\end{array}$ & $\begin{aligned} & \text { Audit }=0.05 * \text { profit }+0.15 * \text { int } . \text { shift }+0.1 * \text { dom. shift }+0.1 \\
& * \text { loss. shift }+0.1 * \text { thin. cap }+0.15 * \text { trans. price } \\
&+0.10 * \text { specific. tp }+0.10 * \text { nonroutine. } t p+0.15 \\
& * \text { loss }\end{aligned}$ & Efendi et al. (2020). & Yes \\
\hline
\end{tabular}




\section{DATA AND SAMPLE SELECTIONS}

This study analyses an unbalanced panel of micro-level tax return data of medium and large firms administered at the Large Taxpayers' Office One, Large Taxpayers' Office Two, and Jakarta Special Regional Tax Office under the Indonesian tax authority (i.e., the Directorate General of Taxes/DGT). ${ }^{9}$ Investigating self-reported confidential tax return data is frequently suggested by previous studies since it is capable of providing actual and direct evidence of firms' tax manipulations by permitting a broader interaction between elements of the income tax law (Oyelere \& Emmanuel, 1998; Plesko, 2003) along with averting survivorship bias caused by database errors and omissions (Conover \& Nichols, 2000; Kinney \& Swanson, 1993; Spooner, 1986). Accordingly, in this study, income tax liability information is collected from the respective annual tax return. Meanwhile, financial performance data are gathered from the firm's nonconsolidated financial statements attached to the tax returns. Both documents are officially provided, upon non-disclosure restrictions, to the author by the Director of Dissemination, Services, and Public Relations of the DGT. However, the corporate income tax returns are provided anonymously. Thus, the author is unable to match specific income tax liability and financial information with the corresponding firm.

Corporate income tax in Indonesia is determined based on a combination of global or comprehensive (i.e., a single tax rate is imposed on all income) and schedular (i.e., separate tax ratesare imposed on different categories of income) tax systems. Broadly, the comprehensive income tax system is applied in every industry. However, to maintain the simplicity of income tax payments and prevent tax revenue losses, some specific retail-based industries (e.g., construction services, real estates, shipping) and incomes (e.g., interest income, property lease income, gain from financial securities' trading) are subject to a schedular-final income tax system. Consequently, the incomes that subject to schedular-final income taxes shall be excluded from the end-year comprehensive income tax calculation through limited negative fiscal adjustments.

Pursuant to Article 17 of Law Number 7 Year 1983 concerning Income Tax as lastly amended by Law Number 36 Year 2008 (Income Tax Law), the statutory corporate income tax rate is set as 28 per cent up to the fiscal year 2009 and 25 per cent starting for the fiscal year 2010 onwards. Furthermore, as part of the government's incentive package in response to the Covid-19 pandemic, the statutory tax rate is further reduced to 22 per cent starting from the fiscal year 2020 up to 2021 and farther discounted to 20 per cent for the fiscal year 2022 onwards. Moreover, as stipulated in Article 3IE of the aforesaid Law, a 50 per cent lower tax rate is applied to every domestic firm (not including permanent establishment) that obtain annual turnover (on a worldwide income basis) up to 50 billion rupiahs. The lower tax rate applies only to some part of the firm's taxable income compared to its annual turnover up to 4.8 billion rupiahs. ${ }^{10}$ Similarly, publicly-listed firms could obtain a five per cent lower tax rate after selling a minimum of 40 per cent of their total shares to more than 300 public investors. Additionally, since mid of 2013, small domestic firms with an annual turnover of fewer than 4.8 billion rupiahs are eligible to enjoy a final income tax at a rate of one per cent from their monthly turnover. Furthermore, the final tax rate is further discounted to 0.5 per cent starting from mid of 2018 onwards.

In addition to the ordinary statutory income tax rates, some capital-intensive industries are eligible to maintain their prevailing income tax rate as stipulated in the respective regulations or contract of works. Specifically, oil and gas firms can maintain the statutory income tax rate stipulated in their production sharing contracts (i.e., broadly 25 to 45 per cent from the equivalent

\footnotetext{
${ }^{9}$ Similar to the majority of tax authorities, DGT administrates corporate taxpayers based on their scale of economy. Accordingly, this study's initial sample consists of the largest domestic and foreign-owned firms in Indonesia, which are administered at the large taxpayers' offices, together with medium and small foreignowned firms and permanent establishments administered at the Jakarta special regional tax office.

${ }^{10}$ The portion of a firm's taxable which subjects to a 50 percent lower income tax rate is calculated using a formula: $(4,800,000,000$ Annual turnover $) x$ Taxable income.
} 
monetary value of oil and gas lifting after deducting first tranche petroleum and cost recoveries (i.e., equity-to-be-split)). Similarly, geothermal, coal, and minerals mining firms can maintain the statutory income tax rate stipulated in their contract of works (i.e., 34 per cent for geothermal firms, 25 to 35 per cent for coal and minerals mining firms). Finally, construction services, real estates, representative offices, shipping, and air transportation providers are subject to schedularfinal income taxes. Table 2 summarises applicable statutory corporate income tax rates for various categories of firms in Indonesia.

TABLE-2: Corporate income tax rates in Indonesia

\begin{tabular}{|c|c|c|}
\hline Group & Category & Statutory Income Tax Rate \\
\hline 1 & $\begin{array}{l}\text { Large firms } \\
\text { (more than } 50 \text { billion rupiahs of } \\
\text { annual turnover) }\end{array}$ & $\begin{array}{l}28 \% \text { in fiscal year } 2009 \\
25 \% \text { in fiscal year } 2010 \text { until } 2019 \\
22 \% \text { in fiscal year } 2020 \text { until } 2021 \\
20 \% \text { in fiscal year } 2022 \text { onwards }\end{array}$ \\
\hline 2 & $\begin{array}{l}\text { Medium firms } \\
\text { (more than } 4.8 \text { up to } 50 \text { billion rupiahs } \\
\text { of annual turnover, Permanent } \\
\text { Establishments are excluded) }\end{array}$ & $\begin{array}{c}\text { 14\% for up to } 4.8 \text { billion rupiahs of taxable income } \\
\text { and } 28 \% \text { for the remaining in fiscal year } 2009 \\
12.5 \% \text { up to up to } 4.8 \text { billion rupiahs of taxable } \\
\text { income and } 25 \% \text { for the remaining in fiscal year } \\
2010 \text { until } 2019 \\
11 \% \text { up to up to } 4.8 \text { billion rupiahs of taxable } \\
\text { income and } 22 \% \text { for the remaining in fiscal year } \\
2020 \text { until } 2021 \\
10 \% \text { up to up to } 4.8 \text { billion rupiahs of taxable } \\
\text { income and } 20 \% \text { for the remaining in fiscal year } \\
2022 \text { onwards }\end{array}$ \\
\hline 3 & $\begin{array}{l}\text { Small firms } \\
\text { (not more than } 4.8 \text { billion rupiahs } \\
\text { million annual turnover, Permanent } \\
\text { Establishments are excluded) }\end{array}$ & $\begin{array}{l}14 \% \text { up to } 4.8 \text { billion rupiahs of taxable income } \\
\text { and } 28 \% \text { for the remaining in fiscal year } 2009 \\
12.5 \% \text { up to } 4.8 \text { billion rupiahs of taxable income } \\
\text { and } 25 \% \text { for the remaining in fiscal year } 2010 \text { until } \\
2012 \\
1 \% \text { of monthly sales (final tax) in fiscal year } 2013 \\
\text { until } 2018 \\
\begin{array}{c}0.5 \% \text { of monthly sales (final tax) in fiscal year } 2019 \\
\text { onwards }\end{array}\end{array}$ \\
\hline 4 & Publicly-listed firms & $\begin{array}{c}23 \% \text { in fiscal year } 2009 \\
20 \% \text { in fiscal year } 2010 \text { until } 2019 \\
19 \% \text { in fiscal year } 2020 \text { until } 2021 \\
17 \% \text { in fiscal year } 2022 \text { onwards }\end{array}$ \\
\hline 5 & Oil and gas firms & $\begin{array}{l}25 \% \text { to } 45 \% \text { from equity to be split varies } \\
\text { conforming to the prevailing statutory corporate } \\
\text { income tax rate in the date of signing of the } \\
\text { production sharing contracts }\end{array}$ \\
\hline 6 & Geothermal firms & $\begin{array}{l}34 \% \text { of net income as stipulated in the contract of } \\
\text { works }\end{array}$ \\
\hline 7 & Coal and mineral mining firms & $\begin{array}{c}25 \text { to } 35 \% \text { varies conforming to the prevailing } \\
\text { statutory corporate income tax rate in the date of } \\
\text { signing of the contract of works }\end{array}$ \\
\hline 8 & Construction service firms & $\begin{array}{c}2 \text { to } 6 \% \text { of gross revenues varies based on type of } \\
\text { services and formal industry qualifications } \\
\text { (final income tax) }\end{array}$ \\
\hline 9 & Real estate firms & $\begin{array}{c}5 \% \text { of gross sales revenues and 10\% of gross lease } \\
\text { revenues (final income tax) }\end{array}$ \\
\hline 10 & Representative offices & $\begin{array}{l}0.44 \% \text { of gross sales of the head office in Indonesia } \\
\text { (final income tax) }\end{array}$ \\
\hline 11 & Financial brokerage firms & $\begin{array}{l}0.1 \% \text { of gross sales of financial securities in the } \\
\text { capital market (final income tax) }\end{array}$ \\
\hline 12 & Shipping and air transportation firms & $\begin{array}{l}1.2 \% \text { of gross revenues for domestic routes and } \\
2.64 \% \text { of gross revenues for international routes } \\
\text { (final income tax) }\end{array}$ \\
\hline
\end{tabular}


This study begins with all firms that are administered at the specified tax offices over 2009 to 2017 fiscal years. The observation period is selected mainly because of the absence of significant regulatory changes during the period after the completion of the most recent income tax reform in 2008, which provides a stable setting for empirical analysis. Initially, a total of 6,784 firms (53,573 firm-years) are considered as the sample for this study. However, considering Indonesia's unique income tax setting and in the direction of selecting a sample group which is comparable to those of other international tax research, this study excludes 153 coal and mineral mining firms; 702 oil, gas, and geothermal firms; 1,886 small firms respectively from the sample because of differences in the statutory corporate income tax rate. Similarly, this study excludes 8,639 firms which are subject to the schedular-final income tax systems, specifically construction services, real estates, stock exchange and settlements, financial brokerages, shipping, and travel agents. It is because their income tax calculation is significantly different compared to those that apply comprehensive income tax system in the sample group. This study also excludes 750 financial service firms because they are subject to the government's prudential regulations, which likely affects their financial reporting incentives and tax compliance behaviour.

Additionally, this study excludes 2,830 loss-making firms with negative Cash ETR and 6,168 firms with excessive income tax payments (i.e., Cash ETR more than one). ${ }^{11}$ Finally, 154 firms that apply incorrect statutory income tax rates are also excluded from the sample. The final sample consists of an unbalanced panel of 4,752 (32,120 firm-years) medium and large firms also Permanent Establishments that subject to 28 and 25 per cent of statutory corporate income tax rates. In term of industry distribution, a substantial proportion of the sample is clustered in non-automotive products wholesale trading (17.02 per cent), basic chemicals manufacturing ( 6.79 per cent), foods manufacturing (5.37 per cent), management services (5.07 per cent), rubber and plastic products manufacturing (4.86 per cent), and oil and gas explorations (4.47 per cent) while others are evenly distributed across various manufacturing, trading, and service industries which indicates a relatively low risk of industry bias. ${ }^{12}$ Panel A of Table 3 summarises the sample selection criteria and Panel B presents the detailed industry distributions.

This study examines the relative ability of sixteen existing tax avoidance measures in predicting firms' long-run income tax burdens. The measures suggested by earlier tax avoidance studies include Cash ETR, Lagged Cash ETR, GAAP ETR, Cash flow ETR, EBIT ETR, Deferred ETR, BTD, Total BTD, Temporary BTD, Book-tax Gap (BTG), SPREAD, Tax Arbitrage, DTAX,TSE, Tax Shelter, and tax authority's audit case selection index. Panel A of Table 4 reports descriptive statistics of the existing measures. It shows, among other, the mean (median) for Cash ETR, Lagged Cash ETR, GAAP ETR, Cash flow ETR, EBIT ETR, and Deferred ETR are 0.1859 (0.2097), 0.1834 (0.2125), 0.1599 (0.1474), 0.1513 (0.0171), 0.1044 (0.0720), 0.1993 (0.2346) respectively indicating that the sample is marginally skewed towards lower ETR firms. Furthermore, the mean Cash ETR is marginally higher than the mean GAAP ETR, suggesting a substantial proportion of sample firms are reporting temporary positive fiscal adjustments (i.e., depreciations, amortisations, allowances). Correspondingly, the mean and median of all BTD- based measures are negative, implying relatively low financial reporting incentives among sample firms together with the soaring risk of conforming tax avoidance schemes. Finally, the mean (median) of audit case selection score is $0.4039(0.4000)$, revealing that the sample firms are utilising multiple tax avoidance schemes and, on average, conforming to DGT's audit policy guideline, have a medium to high corporate tax avoidance risks.

\footnotetext{
${ }^{11}$ Firms have a negative Cash ETR as a result of their fiscal adjustments. Hence, a loss-making firm can havea negative pre-tax commercial income and a positive income tax paid, which lead to a negative Cash ETR. Studies argued that negative Cash ETRs are difficult to interpret (e.g. Dyreng et al., 2008; Dyreng et al., 2017), therefore they are typically excluded from the main sample.

12 This study controls for industry fixed-effects in the OLS regressions.
} 
The mean Cash ETR is substantially lower than the statutory corporate income tax rates of 28 and 25 per cent, which are consistent with previous tax avoidance studies (e.g., Chen et al., 2010; Dyreng et al., 2008; Dyreng et al., 2017; Gupta \& Newberry, 1997). Furthermore, the trend of mean Cash ETR over the observation periods is declining, as shown in Figure 1, conforming to a similar pattern reported in other countries (Dyreng et al., 2017). ${ }^{13}$ Also, compared to mean annual Cash ETR, the mean of the Long-run ETR is considerably higher but still lower than the statutory corporate income tax rates indicating some firms are able to pay a small amount of tax over a longrun period consistent with continual tax avoidance reported by Dyreng et al. (2008). Specifically, Panel B of Table 4 reveals 241 firms (18.12 per cent of the total sample) are capable of maintainingless than 10 per cent of Long-run ETRs. On the other hand, 367 firms (27.59 per cent of the total sample) report their long-run tax burdens of 10 per cent up to the statutory tax rates.

TABLE-3: Sample composition

\begin{tabular}{|c|c|c|c|}
\hline \multicolumn{3}{|l|}{ Sample selection criteria } & $\begin{array}{l}\text { Firm- } \\
\text { years } \\
(2009 \text { - } \\
2017)\end{array}$ \\
\hline \multicolumn{3}{|l|}{$\begin{array}{l}\text { Panel A: Sample selection summary } \\
\text { All firms administered at L arge Taxpavers Off }\end{array}$} & 53,573 \\
\hline \multicolumn{4}{|c|}{ Office Two, and Jakarta Special Regional Tax OfficeLess: } \\
\hline & 2,830 \\
\hline \multicolumn{3}{|c|}{ Firms with excessive income tax payments (Cash ETR>1) } & 6,168 \\
\hline \multicolumn{3}{|c|}{ Small firms } & 1,886 \\
\hline \multicolumn{3}{|c|}{$\begin{array}{l}\text { Coal and mineral mining firms which sign their contract of works } \\
\text { before } 2009\end{array}$} & 153 \\
\hline \multicolumn{3}{|c|}{ Oil and gas firms which sign their production sharing contracts before } & 702 \\
\hline \multicolumn{4}{|c|}{2009} \\
\hline \multicolumn{3}{|l|}{ Geothermal firms } & 171 \\
\hline \multicolumn{3}{|c|}{$\begin{array}{l}\text { Firms that subject to final income tax (e.g. construction services, real } \\
\text { estates, shipping, financial brokerages, travel agents) }\end{array}$} & 8,639 \\
\hline \multicolumn{3}{|c|}{ Financial services firms } & 750 \\
\hline \multicolumn{3}{|c|}{ Firms which apply incorrect statutory income tax rates } & 154 \\
\hline \multicolumn{3}{|c|}{ Final sample } & 32,120 \\
\hline \multicolumn{2}{|l|}{ Industry description* } & $\begin{array}{r}\text { Number of } \\
\text { firms }\end{array}$ & $\begin{array}{l}\text { Firm-years } \\
(2009-2017)\end{array}$ \\
\hline \multicolumn{4}{|l|}{ Panel B: Industry classification } \\
\hline Accommodations and hospitality & 2.10 & 93 & 673 \\
\hline Agriculture & 2.63 & 113 & 846 \\
\hline Automotive manufacturing & 2.94 & 117 & 945 \\
\hline Basic chemicals manufacturing & 6.79 & 273 & 2,181 \\
\hline Clothing and apparels & 3.62 & 179 & 1,162 \\
\hline Electronic and optical parts manufacturing & 2.84 & 124 & 913 \\
\hline Foods manufacturing & 5.37 & 228 & 1,725 \\
\hline Management services & 5.07 & 249 & 1,629 \\
\hline Metal products manufacturing & 3.06 & 131 & 982 \\
\hline Non-automotive wholesale trading & 17.02 & 781 & 5,468 \\
\hline Oil and gas & 4.47 & 405 & 1,436 \\
\hline Rubber and plastic products manufacturing & 4.86 & 213 & 1,562 \\
\hline Textile manufacturing & 3.62 & 159 & 1,164 \\
\hline Warehouse and transportation services & 2.60 & 124 & 835 \\
\hline Wooden products manufacturing & 2.35 & 110 & 756 \\
\hline Other** ${ }^{*}$ & 30.66 & 1,453 & 9,843 \\
\hline Total & 100.00 & 4,752 & 32,120 \\
\hline
\end{tabular}

13 Figure 1 also displays a marginal increase of mean Cash ETR after 2015 due to the recent tax amnesty program. 
TABLE-4: Descriptive statistics and distributions of firms' long-run tax burdens

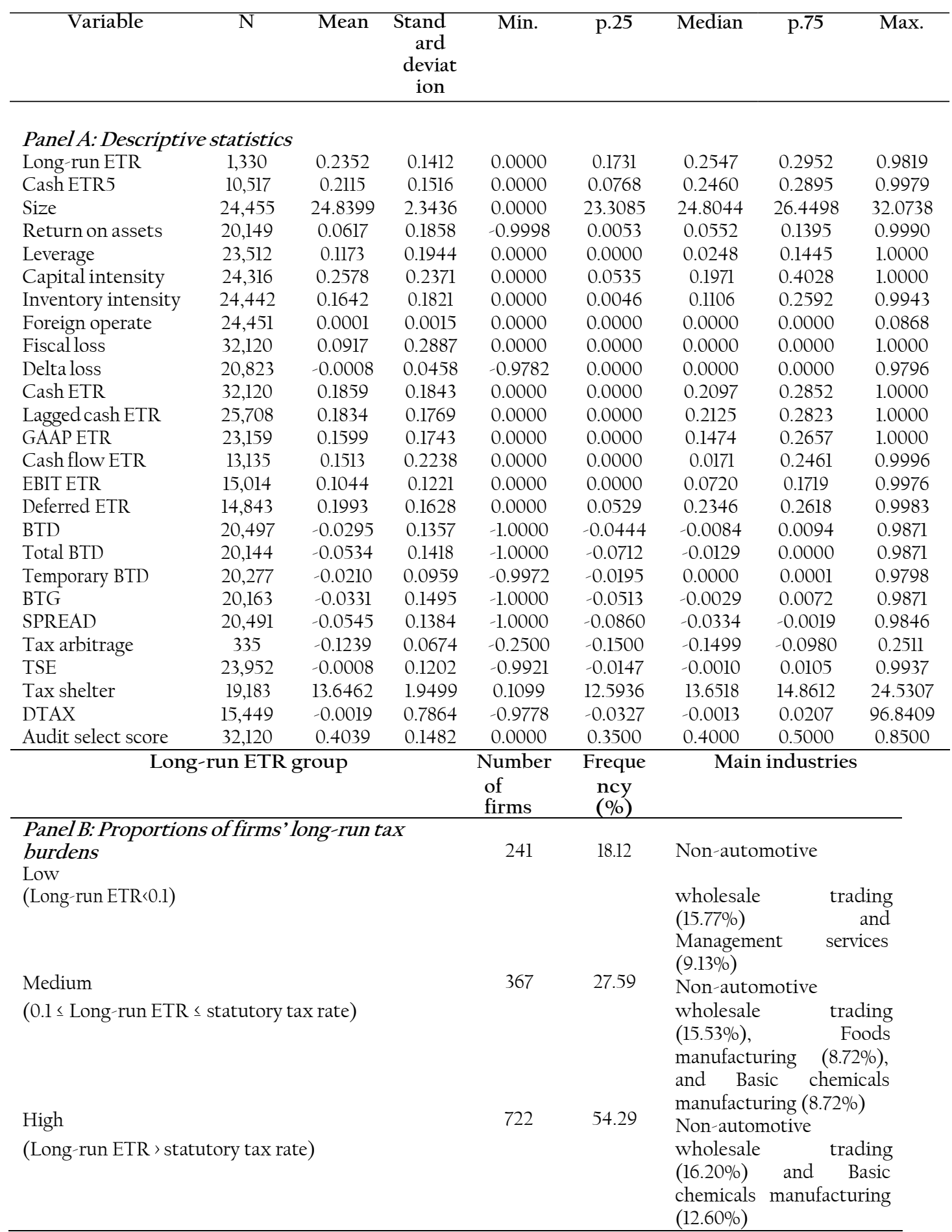

BTD, Total BTD, Temporary BTD, BTG, and SPREAD are scaled by lagged total assets. Return on Assets, Delta Loss, Foreign Operations, TSE, BTD, Temporary BTD, BTG, and SPREAD are censored to - 1 and 1 . Similarly, all ETRs, Leverage, Capital Intensity, and Inventory Intensity are censored to 0 and 1 . Long-run ETR and Cash ETR5 are calculated by, following Dyreng et al. (2008) and Rego and Wilson (2012), dividing aggregate income tax paid by its corresponding aggregate pre-tax income for nine and five consecutive years, respectively. Long-run ETR classifications are following the US Government Accountability Office (1990) criteria.

Table 5 presents the bivariate correlations between the main variables. The table displays positive correlations among ETR-based tax avoidance measures and negative correlations between these measures with non-ETR-based tax avoidance proxies consistent with aggressive firms facing low tax burdens (Dunbar, Higgins, Phillips, \& Plesko, 2010). Moreover, the table reveals that Long-run ETR is, both linearly and monotonically, strongly correlated with Cash ETR and Lagged cash ETR 
while moderately correlated with other ETR-based measures. Additionally, the measure is moderate-linearly correlated with the tax authority's audit selection index also, monotonically, strongly correlated with TSE, and moderately correlated with BTD, Total BTD, and SPREAD. In summary, Table 5 also indicates that collinearity among tax measures is generally low, except for ETR-based measures as a consequence of their specific variable construction and aggregation process.

FIGURE-1: Trend of Cash ETR

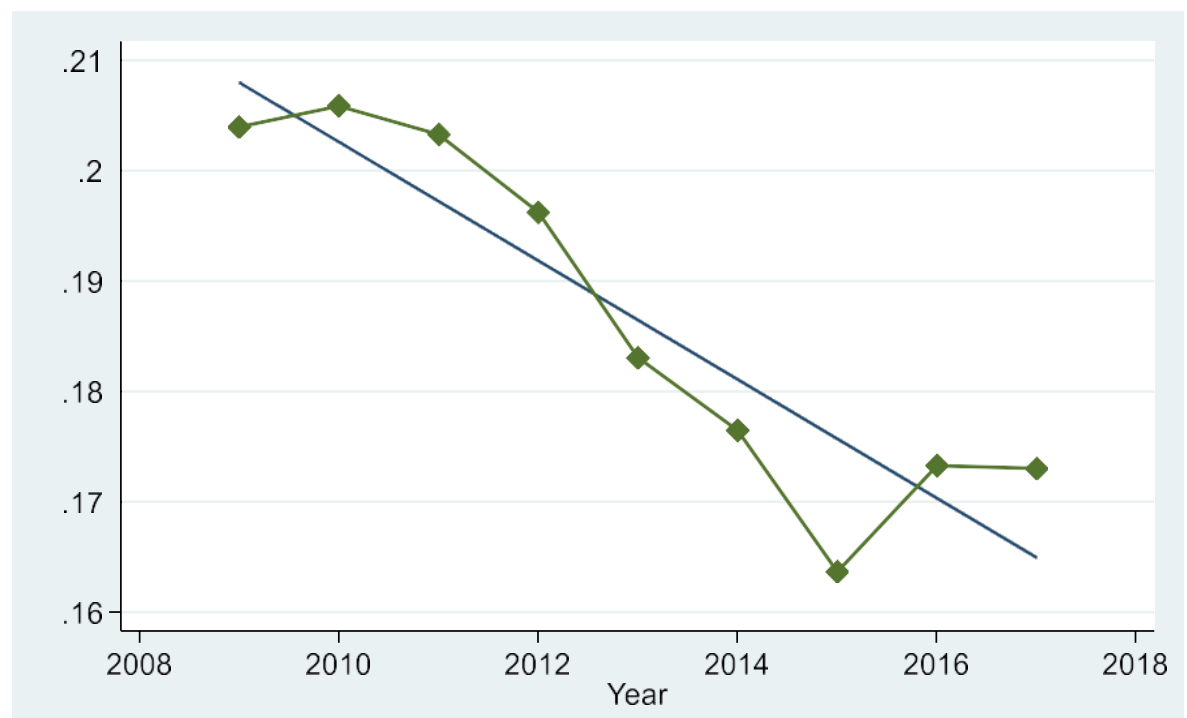

This figure plots the mean of Cash ETR over the observation periods 2009 to 2017. Cash ETR is the ratio of income tax paid to pre-tax income. 
TABLE-5: Bivariate correlations of the main

\begin{tabular}{|c|c|c|c|c|c|c|c|c|c|c|c|c|c|c|c|c|c|c|c|}
\hline \multicolumn{20}{|c|}{ variables } \\
\hline 1 & Long-run & & & $\mathrm{J}$ & 4 & $0.353 *$ & $0.384 *$ & $0389 *$ & $0.412 *$ & $-0.329 *$ & $-0.336 *$ & $\frac{11}{-0.161 *}$ & $-0.185 *$ & $-0.303 *$ & 10.197 & $-0.531 *$ & -0.025 & $-0,052$ & $\frac{10}{-0.187 *}$ \\
\hline & ETR & & 0.858 & $0.565 *$ & & & & & & & & & & & & & & & \\
\hline 2 & Cash ETR5 & $0.766^{*}$ & & $0.706^{*}$ & $0.755^{*}$ & $0.418^{*}$ & $0.548^{*}$ & $0.477^{*}$ & $0.462 *$ & $-0.283^{*}$ & $-0.281 *$ & $-0.222 *$ & $-0.113 *$ & $-0.299 *$ & -0.073 & $-0.527 *$ & $0.055^{*}$ & $-0.070 *$ & $-0.335 *$ \\
\hline 3 & Cash ETR & $0.604 *$ & $0.629^{*}$ & & $0.751 *$ & $0.518^{*}$ & $0.864 *$ & $0.748^{*}$ & $0.579 *$ & $-0.132 *$ & $-0.245 *$ & $-0.308^{*}$ & $-0.036^{*}$ & $-0.205^{*}$ & 0.023 & $-0.375^{*}$ & $0.153^{*}$ & -0.002 & $-0.369 *$ \\
\hline 4 & Lag Cash & $0.622 *$ & $0.693^{*}$ & $0.735^{*}$ & & $0.423^{*}$ & $0.680 *$ & $0.582^{*}$ & $0.477^{*}$ & $-0.109 *$ & $-0.209 *$ & $-0.242^{*}$ & $-0.049 *$ & $-0.197 *$ & 0.014 & $-0.344 *$ & $0.152 *$ & -0.011 & $-0.379 *$ \\
\hline 5 & $\begin{array}{l}\text { ETR } \\
\text { GAAP ETR }\end{array}$ & $0.365^{*}$ & $0.391^{*}$ & $0.574 *$ & $0.438^{*}$ & & $0.483^{*}$ & $0.425^{*}$ & $0.660^{*}$ & $-0.052 *$ & $-0.108 *$ & $0.315^{*}$ & $-0.435^{*}$ & $-0.106^{*}$ & 0.095 & $-0.216^{*}$ & $0.226^{*}$ & $-0.328 *$ & $-0.303^{*}$ \\
\hline 6 & Cash flow & $0.392 *$ & $0.405^{*}$ & $0.582 *$ & $0.465^{*}$ & $0.317 *$ & & $0.893^{*}$ & $0.527^{*}$ & $0.237^{*}$ & $-0.092 *$ & $-0.278^{*}$ & $0.074 *$ & -0.014 & -0.133 & -0.095 & $0.375^{*}$ & $0.071^{*}$ & $-0.476^{*}$ \\
\hline 7 & ETR ETR & $0.445^{*}$ & $0.459^{*}$ & $0.666^{*}$ & $0.550^{*}$ & $0.387 *$ & $0.551 *$ & & $0.559^{*}$ & $0.1009 *$ & $0.115^{*}$ & $-0.251^{*}$ & $0.229 *$ & $-0.149 *$ & -0.062 & -0.144 & $0.395^{*}$ & $0.096^{*}$ & $-0.420^{*}$ \\
\hline 8 & Deferred & $0.432 *$ & $0.424^{*}$ & $0.604 *$ & $0.469^{*}$ & $0.790 *$ & $0.318^{*}$ & $0.409^{*}$ & & $-0.029 *$ & $-0.074 *$ & 0.027 & $-0.227 *$ & $-0.083 *$ & 0.091 & $-0.221 *$ & $0.186^{*}$ & $-0.107 *$ & $-0.279 *$ \\
\hline 9 & $\begin{array}{l}\text { ETR } \\
\text { BTD }\end{array}$ & 0.064 & -0.012 & 0.013 & -0.000 & 0.075 & 0.032 & 0.018 & 0.060 & & $0.469^{*}$ & $0.132 *$ & $0.390^{*}$ & $0.880^{*}$ & -0.119 & $0.518^{*}$ & $0.361 *$ & $0.278^{*}$ & $-0.134 *$ \\
\hline 10 & Total BTD & 0.054 & 0.004 & 0.040 & 0.004 & 0.087 & 0.047 & 0.026 & 0.056 & $0.902^{*}$ & & $0.185^{*}$ & $0.664^{*}$ & $0.502 *$ & 0.017 & $0.303^{*}$ & $0.165^{*}$ & $0.369^{*}$ & $-0.039 *$ \\
\hline 11 & Temporary & $-0.112 *$ & $-0.130^{*}$ & $-0.186^{*}$ & $-0.147 *$ & $0.290 *$ & $-0.198 *$ & $-0.194 *$ & $0.139^{*}$ & $0.254^{*}$ & $0.199 *$ & & $-0.385^{*}$ & $0.173 *$ & 0.037 & $0.168^{*}$ & -0.007 & $-0.355^{*}$ & $0.106^{*}$ \\
\hline 12 & $\begin{array}{l}\text { BTD } \\
\text { BTG }\end{array}$ & $0.143^{*}$ & 0.089 & $0.156^{*}$ & $0.114^{*}$ & $-0.142 *$ & $0.178^{*}$ & $0.159^{*}$ & -0.053 & $0.693^{*}$ & $0.675^{*}$ & $-0.505^{*}$ & & $0.384 *$ & -0.049 & $0.189^{*}$ & $0.139 *$ & $0.637 *$ & $-0.069 *$ \\
\hline 13 & SPREAD & -0.055 & $-0.127 *$ & $-0.151^{*}$ & $-0.140 *$ & -0.027 & $-0.149 *$ & $-0.168 *$ & -0.039 & $0.933^{*}$ & $0.837 *$ & $0.336^{*}$ & $0.573^{*}$ & & 0.046 & $0.427^{*}$ & $0.222 *$ & $0.282^{*}$ & -0.001 \\
\hline 14 & $\begin{array}{l}\text { Tax } \\
\text { Arbitrage }\end{array}$ & 0.335 & 0.049 & -0.019 & -0.298 & -0.028 & 0.687 & -0.630 & -0.018 & 0.042 & 0.042 & -0.118 & 0.137 & 0.354 & & -0.078 & $\begin{array}{c}- \\
0.199 *\end{array}$ & -0.027 & -0.010 \\
\hline 15 & TSE & -0.099 & $-0.258^{*}$ & -0.102 & $-0.166^{*}$ & 0.006 & -0.072 & -0.082 & -0.036 & $0.224 *$ & $0.159^{*}$ & $0.161 *$ & 0.089 & $0.236^{*}$ & 0.022 & & $0.098 *$ & $0.118^{*}$ & $0.055^{*}$ \\
\hline 16 & Tax Shelter & $0.142 *$ & $0.111^{*}$ & $0.209^{*}$ & $0.129 *$ & $0.191^{*}$ & $0.250^{*}$ & $0.237^{*}$ & $0.206^{*}$ & $0.467 *$ & $0.435^{*}$ & -0.005 & $0.379 *$ & $0.282^{*}$ & -0.235 & $0.169^{*}$ & & $0.066^{*}$ & $-0.438 *$ \\
\hline 17 & DTAX & 0.087 & 0.065 & 0.093 & 0.075 & $-0.159 *$ & 0.102 & 0.098 & -0.079 & $0.447^{*}$ & $0.485^{*}$ & $-0.449^{*}$ & $0.761^{*}$ & $0.374 *$ & -0.490 & 0.017 & $0.169 *$ & & -0.014 \\
\hline 18 & $\begin{array}{l}\text { Audit } \\
\text { Scores }\end{array}$ & $-0.375^{*}$ & $-0.386^{*}$ & $-0.391 *$ & $-0.359 *$ & $-0.250 *$ & $-0.333 *$ & $-0.339 *$ & $\begin{array}{c}- \\
0.313^{*}\end{array}$ & $-0.198 *$ & $-0.192 *$ & 0.060 & $-0.222 *$ & -0.098 & -0.496 & 0.035 & $\begin{array}{c}- \\
0.431 *\end{array}$ & $-0.126^{*}$ & \\
\hline
\end{tabular}

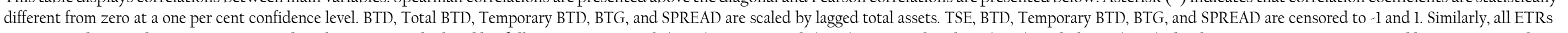

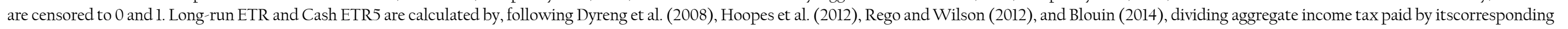
aggregate pre-tax income for nine and five consecutive years, respectively. 


\section{EMPIRICAL RESULTS}

This exploratory study focuses on examining the reliability of existing tax avoidance measures in predicting firms' long-run tax burdens and, thus, proposes the most informative proxy as the tax authorities' bailout verification instrument. Table 6 reports the comparative strength of these measures by estimating the regression model (2). It reveals that using both univariate and multivariate estimations, entire ETR-based measures, TSE, and the tax authority's audit selection scores are statistically significant $(p 0.01)$ to Long-run ETR. However, their magnitudes are substantially smaller than one. They vary between a low of 0.0976 (Cash flow ETR) to a high of 0.3922 (Lagged Cash ETR), also their explanatory powers are limited and range from a low of 0.0322 (TSE) to a high of 0.2524 (Lagged Cash ETR). Conversely, every BTD-based measure (except for Temporary BTD) is only significant ( $p(0.01)$ in the multivariate estimations indicating these proxies' sensitiveness to the inclusion of control variables. Furthermore, Tax Arbitrage and Temporary BTD are not significant in both univariate and multivariate estimations exposing their low reliabilities in estimating long-run income tax burdens. ${ }^{14}$

Additionally, in investigating the relative ability of these measures in explaining variations of firms' long-run tax burdens, this study begins by transforming Total BTD, SPREAD, and Tax Shelter into their residual forms after, individually, regressing BTD to these BTD-based measures (as in Efendi et al., 2020). The variable transformations are critical in lessening structural multicollinearity problems caused by cross-correlations between these measures (i.e., all measures have BTD components in their respective variable constructions) and assure sufficient orthogonality of the explanatory variables. Further, following Lisowsky et al. (2013) and Efendi et al. (2020), this study assigns the measures which retain a significant association with Long-run ETR in the individual multivariate estimation of equation (2) in one regression model (3) and allow them to 'compete'. Table 7 reports the results of this estimation. The regression reveals that only Lagged Cash ETR, BTD, and Fiscal Loss, a control variable, are statistically significant ( $p$ 0.05) to Long-run ETR. Nevertheless, their weights are also substantially smaller than one.

In summary, the regression analyses suggest that, in comparison, Lagged Cash ETR presents more information about Long-run ETR and, thus, the most reliable proxy in estimating firms' long-run tax burdens. This result is theoretically supported since, acting as a 'profit centre' in generating more earnings, firms' tax departments will consider their prior tax burdens as the primary determinant in selecting their 'level' of aggressiveness and tax avoidance strategies (Lisowsky, 2010).

${ }^{14}$ Tax Arbitrage's less usefulness is, primarily, caused by the attrition of sample size in both univariate and multivariate OLS regressions due to the limited number of sample firms which repatriate their income to Indonesia. 
TABLE-6: Comparative reliabilities of existing tax avoidance measures and the tax authority's internal measure in predicting long-run tax burdens.

\begin{tabular}{|c|c|c|c|}
\hline \begin{tabular}{l}
\multicolumn{1}{c}{ Tax } \\
avoidance \\
measures
\end{tabular} & $\begin{array}{l}\text { Predicte } \\
\text { dsign }\end{array}$ & Univariate & Multivariate \\
\hline \multirow[t]{2}{*}{ CashETR } & + & $0.3744(12.70)^{* * *}$ & $0.3110(8.85)^{* * *}$ \\
\hline & & $\mathrm{N}=1,330 R^{2}=18.21$ & $\mathrm{~N}=1,070 R^{2}=22.12$ \\
\hline \multirow[t]{2}{*}{ Lagged Cash ETR } & + & $0.3922(14.11)^{* * * *}$ & $0.3536(10.35)^{* * *}$ \\
\hline & + & $\begin{array}{l}\mathrm{N}=1,330 R^{2}=21.410 .2263 \\
(8.03)^{* * *}\end{array}$ & $\begin{array}{l}\mathrm{N}=1,070 R^{2}=25.24 \\
0.3346(9.39)^{* * *}\end{array}$ \\
\hline GAAP ETR & & $\mathrm{N}=1,089 R^{2}=7.45$ & $\mathrm{~N}=1,099 R^{2}=25.06$ \\
\hline \multirow[t]{2}{*}{ Cash flow ETR } & + & $0.1557(8.59)^{* * *}$ & $0.0976(4.85)^{* * *}$ \\
\hline & + & $\begin{array}{l}\mathrm{N}=745 R^{2}=6.210 .3422 \\
(9.74)^{* * *}\end{array}$ & $\begin{array}{l}\mathrm{N}=687 R^{2}=15.26 \\
0.3317(8.13)^{* * * *}\end{array}$ \\
\hline \multirow[t]{2}{*}{ Deferred ETR } & + & $\begin{array}{l}\mathrm{N}=1,121 R^{2}=10.860 .2948 \\
(8.83)^{* * *}\end{array}$ & $\begin{array}{l}\mathrm{N}=1,041 R^{2}=19.57 \\
0.2289(6.52)^{* * *}\end{array}$ \\
\hline & - & $\begin{array}{l}\mathrm{N}=1,025 R^{2}=11.000 .0036 \\
\quad(0.05)\end{array}$ & $\begin{array}{c}\mathrm{N}=956 R^{2}=18.49 \\
-0.4287(-5.21)^{* * *}\end{array}$ \\
\hline Book-tax Differences & & $\mathrm{N}=1,142 R^{2}=0.00$ & $\mathrm{~N}=1,070 R^{2}=15.74$ \\
\hline \multirow[t]{2}{*}{ Total BTD } & - & $-0.0300(-0.47)$ & $-0.4123(-5.26)^{* * *}$ \\
\hline & & $\mathrm{N}=1,137 \quad R^{2}=0.05$ & $\mathrm{~N}=1,070 \quad R^{2}=15.65$ \\
\hline \multirow[t]{2}{*}{ Temporary BTD } & - & $-0.0825(-1.25)$ & $-0.0467(-0.51)$ \\
\hline & & $\mathrm{N}=1,141 \quad R^{2}=0.27$ & $\mathrm{~N}=1,070 R^{2}=11.86$ \\
\hline \multirow[t]{2}{*}{ Book-tax Gap } & - & $-0.0007(-0.01)$ & $-0.2143(-2.93)^{* * *}$ \\
\hline & & $\mathrm{N}=1,135 \quad R^{2}=0.00$ & $\mathrm{~N}=1,070 R^{2}=13.52$ \\
\hline \multirow[t]{2}{*}{ SPREAD } & - & $-0.0933(-1.45)$ & $-0.3323(-5.25)^{* * *}$ \\
\hline & & $\mathrm{N}=1,142 R^{2}=0.45$ & $\mathrm{~N}=1,070 R^{2}=15.60$ \\
\hline \multirow[t]{2}{*}{ Tax Arbitrage } & - & $0.1267(1.65)$ & $-0.1052(-0.26)$ \\
\hline & & $\mathrm{N}=17 R^{2}=1.78$ & $\mathrm{~N}=13 R^{2}=84.85$ \\
\hline \multirow[t]{2}{*}{ Tax Subsidy on Equity } & - & $-0.3849(-2.98)^{* * *}$ & $-0.3967(-3.02)^{* * *}$ \\
\hline & & $\mathrm{N}=1,136 R^{2}=3.22$ & $\mathrm{~N}=1,061 R^{2}=14.80$ \\
\hline \multirow[t]{2}{*}{ Tax Shelter } & - & $0.0009(0.29)$ & $-0.0647(-5.21)^{* * *}$ \\
\hline & - & $\begin{array}{l}\mathrm{N}=1,104 R^{2}=0.010 .0327 \\
(0.49)\end{array}$ & $\begin{array}{c}\mathrm{N}=1,069 R^{2}=15.74 \\
-0.1325(-1.79)^{*}\end{array}$ \\
\hline DTAX & & $\mathrm{N}=1,109 R^{2}=0.04$ & $\mathrm{~N}=1,070 R^{2}=12.35$ \\
\hline \multirow[t]{2}{*}{ Audit selection index } & - & $-0.2057(-7.05)^{* * *}$ & $-0.1426(-3.69)^{* * *}$ \\
\hline & & $\mathrm{N}=1,330 \quad R^{2}=4.17$ & $\mathrm{~N}=1,070 R^{2}=13.12$ \\
\hline
\end{tabular}

This table reports the coefficient $(\beta)$ of each tax avoidance measure from an individual estimation using this regression model:

$$
\text { LongrunETR }_{i}=\alpha+\beta T A M_{i}+\Sigma \delta_{k} \operatorname{CONTROLS}_{i}+\Sigma \theta_{l} I N D U S T R Y_{l}+\varepsilon_{i t}
$$

The dependent variable is Long-run ETR which measured by dividing aggregate income tax paid with its corresponding aggregate pre-tax income for nine consecutive years. Univariate regressions exclude all control variables while multivariate regressions include Size (measured as the natural log of total assets), Foreign operations (measured as foreign income scaled by total assets), Leverage, Capital Intensity (measured as total non-current assets scaled by total assets), Inventory Intensity (measured as inventory scaled by total assets), Return on Assets (measured as net profit scaled by total assets), Fiscal Loss (measured as dummy variable coded one if the firm has fiscal loss compensation and 0 otherwise), Changes in Fiscal Loss Compensation (measured as changes in fiscal loss carry-forward scaled by lagged total assets), and industry fixed effects using two-digit of Indonesia's standard industry classification developed by the Central Bureau of Statistics of Indonesia (2015). Existing tax avoidance measures definitions are provided in Table 1. BTD, Total BTD, Temporary BTD, BTG, and SPREAD are scaled by lagged total assets. Return on Assets, Delta Loss, Foreign Operations, BTD, Temporary BTD, BTG, TSE, and SPREAD are censored to -1 and l. Similarly, all ETRs, Leverage, Capital Intensity, and Inventory Intensity are censored to 0 and 1 . Standard errors are robust and clustered by firms. Tstatistics are displayed in parentheses. $R^{2}$ is stated in percentage (\%). The asterisk $\left(^{*}\right)$ indicates the statistical significance of the coefficients at 1 per cent $(* * *), 5$ per cent $(* *)$, and 10 per cent $(*)$ significance level, respectively. 
Table-7: Multivariate regression analysis on reliabilities of existing tax avoidance measures and the tax authority's internal measure in predicting long-run tax burdens.

\begin{tabular}{|c|c|c|c|}
\hline Variable & Predicted sign & Coefficient & t-statistic \\
\hline Cash ETR & + & 0.0989 & 1.49 \\
\hline Lagged cash ETR & + & 0.1852 & $3.93^{* * *}$ \\
\hline GAAP ETR & + & -0.0204 & -0.25 \\
\hline Cash flow ETR & + & 0.0023 & 0.13 \\
\hline EBIT ETR & + & 0.0276 & 0.69 \\
\hline Deferred ETR & + & 0.1101 & 1.44 \\
\hline Book-tax differences & - & -0.3022 & $-2.04 * *$ \\
\hline Total BTD_residual & - & 0.1127 & 0.28 \\
\hline Book-tax gap & - & 0.0915 & 0.93 \\
\hline SPREAD_residual & - & -0.6990 & -1.55 \\
\hline Tax subsidy in equity & - & -0.0773 & -0.33 \\
\hline Tax shelter_residual & - & -0.0209 & -0.58 \\
\hline Audit selection score & - & -0.0835 & -1.58 \\
\hline Size & \pm & 0.0005 & 0.15 \\
\hline Foreign & - & -1.4552 & -0.31 \\
\hline Capital intensity & - & 0.0100 & 0.35 \\
\hline Inventory intensity & + & 0.0574 & 1.30 \\
\hline Return on assets & + & -0.0680 & -0.43 \\
\hline Fiscal loss & - & 0.0929 & $2.29 * *$ \\
\hline Changes in loss & - & 0.2048 & 0.57 \\
\hline Constant & & 0.1285 & 1.20 \\
\hline Industry fixed effect & & Yes & \\
\hline Year fixed effect & & No & \\
\hline $\mathrm{N}$ & & 572 & \\
\hline$R^{2}$ & & 29.70 & \\
\hline \multicolumn{4}{|c|}{ 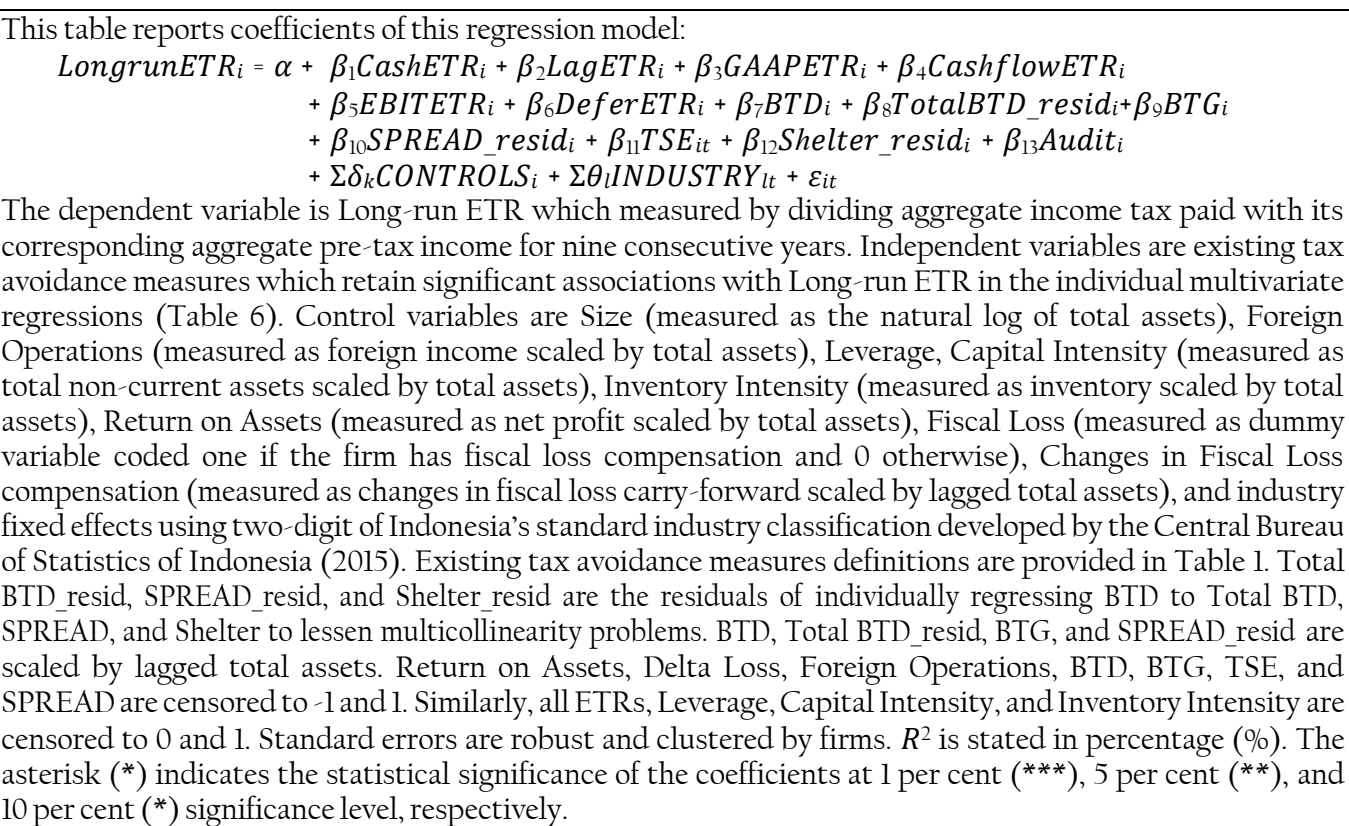 } \\
\hline
\end{tabular}




\section{SENSITIVITY ANALYSIS}

This study evaluates the sensitivity of initial findings on reliabilities of the existing tax avoidance measures in reflecting long-run income tax burdens by testing their abilities in predicting firms' medium-run tax burdens as proposed by previous studies (e.g. Dyreng et al., 2008; Rego \& Wilson, 2012). This study begins with constructing a proxy of medium-run income tax burdens (i.e., Cash ETR5) by, following Dyreng et al. (2008), dividing five consecutive years' aggregate tax paid with its corresponding aggregate pre-tax income. Furthermore, this study develops a supplementary regression model by assigning Cash ETR5 as the dependent variable while existing tax avoidance measures, together with some control variables, are treated as the explanatory variables. This study estimates the regression model (4) for individual tax avoidance measure using multiple specifications (i.e., univariate, multivariate, OLS, fixed effect-panel data) $: 15$

$$
\operatorname{CashETR}_{i t}=\alpha+\beta \operatorname{TAM}_{i}+\Sigma \delta_{k} \operatorname{CONTROLS}_{i t}+\Sigma \theta_{l} \operatorname{INDUSTRY}_{l}+\Sigma \gamma_{m} Y E A R_{m t}+\varepsilon_{i}
$$

The variable of interest is individual tax avoidance measure-TAM. If existing tax avoidance measures are capable of predicting medium-run income tax burdens, the regression results of equation (4) need to present a statistically significant coefficient of TAM with $\beta$ close to one. Contrarily, if these measures are weak proxies of firms' medium-run tax burdens, the coefficient should be insignificant.

Through examining deviations of individual means, panel data models are capable of correcting estimation bias caused by serial correlations of explanatory variables and omittedindividual effects. However, it may simultaneously exacerbate the negative correlations between errors in the variable's measurement and the model's residuals (Griliches $\&$ Hausman, 1986; Plesko, 2003). Hence, if the existing measures contain some measurement errors, we should observe a substantially lower value of $\beta$ (i.e., bias toward zero) in the regression model (4) estimated by panel data models compared to those predicted by OLS regressions.

Table 8 presents the results of these estimations. It reveals that, using univariate and multivariate OLS estimations, the existing measures (except for Tax Arbitrage) are statistically significant ( $p 0.01)$ to Cash ETR5, confirming their reliabilities in predicting medium-run income tax burdens. However, their magnitudes are substantially smaller than one. They vary between a low of -0.0809 (DTAX) to a high of 0.6005 (Lagged Cash ETR) also their explanatory powers are limited and range from a low of 0.0046 (Tax shelter) to a high of 0.4419 (Lagged Cash ETR). Moreover, some proxies (i.e., BTD, Book-tax Gap, DTAX) are sensitive to the inclusion of control variables to the model, which make them less informative in the univariate estimations.

Correspondingly, employing univariate and multivariate fixed effect-panel data estimations does not change the measures' significances except for Cash flow ETR and DTAX which are significant only in the multivariate panel data regressions (i.e., they become sensitive to the inclusion of control variables). In contrast, Temporary BTD and the tax authority's audit selection index become less meaningful in explaining variations of medium-run income taxburdens over time. Furthermore, compared to the results of OLS regressions, the measures' weights are substantially reduced from a low of -0.0135 (Tax shelter) to a high of -0.0956 (BTD), which indicate attenuation biases caused by serial correlations of measurement errors in the existing measures, consistent with identical biases reported by previous studies (e.g., Blouin, 2014; Desai \& Dharmapala, 2006; Efendi et al., 2020; Plesko, 1999, 2003).

\footnotetext{
15 This study initiates the panel data estimations by examining the correlations between time-invariant factors and the model's residuals. Employing Hausman specification tests (untabulated), this study finds time-invariant factors are significantly correlated with the model's residuals implying a fixed effect-panel data model is consistent also unbiased and, hence, the proper identification choice for the sample group.
} 
TABLE 8: Comparative reliabilities of existing tax avoidance measures and the tax authority's internal measure in predicting medium-run tax burdens.

\begin{tabular}{|c|c|c|c|c|c|}
\hline \multirow{2}{*}{$\begin{array}{c}\text { Tax } \\
\text { avoidance } \\
\text { measures }\end{array}$} & \multirow{2}{*}{$\begin{array}{c}\text { Predicte } \\
\text { dsign }\end{array}$} & \multicolumn{2}{|c|}{ Ordinary least squares } & \multicolumn{2}{|c|}{ Fixed effects-panel data } \\
\hline & & Univariate & Multivariate & Univariate & Multivariate \\
\hline \multirow[t]{4}{*}{ Cash ETR } & + & 0.5406 & 0.4442 & 0.0477 & 0.0372 \\
\hline & & $(42.18)^{* * *}$ & $(27.93)^{* * *}$ & $(6.08)^{* * *}$ & $(4.23)^{* * *}$ \\
\hline & & $\mathrm{N}=10,517$ & $\mathrm{~N}=7,841$ & $\mathrm{~N}=10,517(3,109)$ & $\mathrm{N}=8,113(2,436)$ \\
\hline & & $R^{2}=37.41$ & $R^{2}=37.56$ & $R^{2}=37.41$ & $R^{2}=0.18$ \\
\hline Lagged Cash & + & 0.6005 & 0.5272 & 0.0721 & 0.0636 \\
\hline \multirow[t]{3}{*}{ ETR } & & $(50.54)^{* * *}$ & $(33.83)^{* * *}$ & $(8.98)^{* * *}$ & $(6.88)^{* * *}$ \\
\hline & & $\mathrm{N}=10,517$ & $\mathrm{~N}=7,841$ & $\mathrm{~N}=10,517(3,109)$ & $\mathrm{N}=8,113(2,436)$ \\
\hline & & $R^{2}=44.19$ & $R^{2}=43.16$ & $R^{2}=44.19$ & $R^{2}=3.52$ \\
\hline \multirow[t]{4}{*}{ GAAP ETR } & + & 0.3221 & 0.2399 & 0.0281 & 0.0312 \\
\hline & & $(21.35)^{* * *}$ & $(16.14)^{* * *}$ & $(3.69)^{* * *}$ & $(4.02)^{* * *}$ \\
\hline & & $\mathrm{N}=8,235$ & $\mathrm{~N}=7,399$ & $\mathrm{~N}=8,235(2,513)$ & $\mathrm{N}=7,655(2,383)$ \\
\hline & & $R^{2}=13.75$ & $R^{2}=22.64$ & $R^{2}=13.75$ & $R^{2}=0.20$ \\
\hline Cash flow & + & 0.2561 & 0.1463 & -0.0190 & -0.0099 \\
\hline \multirow[t]{3}{*}{ ETR } & & $(26.47)^{* * *}$ & $(13.70)^{* * *}$ & $(-2.43)^{* *}$ & $(-1.23)$ \\
\hline & & $N=5,423$ & $\mathrm{~N}=4,846$ & $\mathrm{~N}=5,423(2,25 \mathrm{l})$ & $\mathrm{N}=5,030(2,154)$ \\
\hline & & $R^{2}=14.03$ & $R^{2}=22.71$ & $R^{2}=14.03$ & $R^{2}=2.79$ \\
\hline \multirow[t]{4}{*}{ EBIT ETR } & + & 0.4473 & 0.3640 & -0.0318 & -0.0271 \\
\hline & & $(20.71)^{* * *}$ & $(15.46)^{* * *}$ & $(-2.34)^{* *}$ & $(-1.93)^{*}$ \\
\hline & & $\mathrm{N}=6,293$ & $\mathrm{~N}=5,784$ & $\mathrm{~N}=6,293(2,261)$ & $\mathrm{N}=5,934(2,147)$ \\
\hline & & $R^{2}=14.94$ & $R^{2}=22.41$ & $R^{2}=14.94$ & $R^{2}=5.58$ \\
\hline Deferred & + & 0.3504 & 0.2547 & -0.0318 & -0.0271 \\
\hline \multirow[t]{3}{*}{ ETR } & & $(21.63)^{* * *}$ & $(16.72)^{* * *}$ & $(-2.34)^{* *}$ & $(-1.93)^{*}$ \\
\hline & & $\mathrm{N}=6,534$ & $\mathrm{~N}=6,013$ & $\mathrm{~N}=6,293(2,261)$ & $\mathrm{N}=5,934(2,147)$ \\
\hline & & $R^{2}=13.90$ & $R^{2}=22.82$ & $R^{2}=14.94$ & $R^{2}=5.58$ \\
\hline Book-tax & - & -0.0099 & -0.3798 & -0.0956 & -0.0742 \\
\hline \multirow[t]{3}{*}{ Differences } & & $(-0.35)$ & $(-11.13)^{* * *}$ & $(-9.22)^{* * *}$ & $(-3.48)^{* * *}$ \\
\hline & & $\mathrm{N}=8,600$ & $\mathrm{~N}=7,834$ & $\mathrm{~N}=8,600(2,546)$ & $\mathrm{N}=6,026(2,166)$ \\
\hline & & $R^{2}=0.01$ & $R^{2}=19.96$ & $R^{2}=0.01$ & $R^{2}=0.94$ \\
\hline \multirow[t]{4}{*}{ Total BTD } & - & -0.1199 & -0.2028 & -0.0316 & -0.0440 \\
\hline & & $(-5.57)^{* * *}$ & $(-8.53)^{* * *}$ & $(-3.63)^{* * *}$ & $(-4.34)^{* * *}$ \\
\hline & & $\mathrm{N}=8,506$ & $\mathrm{~N}=7,837$ & $\mathrm{~N}=8,506(2,520)$ & $\mathrm{N}=8,093(2,434)$ \\
\hline & & $R^{2}=1.04$ & $R^{2}=18.21$ & $R^{2}=1.04$ & $R^{2}=1.21$ \\
\hline Temporary & - & -0.2119 & -0.1429 & 0.0003 & -0.0169 \\
\hline \multirow[t]{3}{*}{ BTD } & & $(-9.89)^{* * *}$ & $(-6.39)^{* * *}$ & $(0.03)$ & $(-1.38)$ \\
\hline & & $\mathrm{N}=8,550$ & $\mathrm{~N}=7,836$ & $\mathrm{~N}=8,550(2,532)$ & $\mathrm{N}=8,097(2,435)$ \\
\hline & & $R^{2}=1.70$ & $R^{2}=16.63$ & $R^{2}=1.70$ & $R^{2}=2.19$ \\
\hline Book-tax & - & -0.0076 & -0.0865 & -0.0347 & -0.0233 \\
\hline \multirow[t]{3}{*}{ Gap } & & $(-0.45)$ & $(-5.29)^{* * *}$ & $(-4.59) * * *$ & $(-2.77)^{* * *}$ \\
\hline & & $\mathrm{N}=8,508$ & $\mathrm{~N}=7,841$ & $\mathrm{~N}=8,508(2,523)$ & $\mathrm{N}=8,089(2,435)$ \\
\hline & & $R^{2}=0.01$ & $R^{2}=16.47$ & $R^{2}=0.01$ & $R^{2}=2.24$ \\
\hline \multirow[t]{4}{*}{ SPREAD } & - & -0.1082 & -0.2983 & -0.0848 & -0.0826 \\
\hline & & $(-3.89)^{* * *}$ & $(-10.84)^{* * *}$ & $(-8.47)^{* * *}$ & $(-5.75)^{* * *}$ \\
\hline & & $\mathrm{N}=8,599$ & $\mathrm{~N}=7,834$ & $\mathrm{~N}=8,599(2,546)$ & $\mathrm{N}=8,096(2,434)$ \\
\hline & & $R^{2}=0.83$ & $R^{2}=19.86$ & $R^{2}=0.83$ & $R^{2}=0.15$ \\
\hline $\operatorname{Tax}$ & - & 0.0225 & -0.0857 & 0.0043 & 0.0186 \\
\hline \multirow[t]{3}{*}{ Arbitrage } & & $(0.14)$ & $(-0.52)$ & $(0.06)$ & $(0.49)$ \\
\hline & & $\mathrm{N}=168$ & $\mathrm{~N}=114$ & $\mathrm{~N}=168(82)$ & $\mathrm{N}=118(57) R^{2}=1.99$ \\
\hline & & $R^{2}=0.01$ & $R^{2}=50.77$ & $R^{2}=0.01$ & \\
\hline \multirow{4}{*}{$\begin{array}{l}\text { Tax Subsidy } \\
\text { on Equity }\end{array}$} & - & -0.3285 & -0.2902 & -0.0947 & -0.0847 \\
\hline & & $(-7.92)^{* * *}$ & $(-6.89)^{* * *}$ & $(-9.08)^{* * *}$ & $(-7.34)^{* * *}$ \\
\hline & & $\mathrm{N}=8,619$ & $\mathrm{~N}=7,781$ & $\mathrm{~N}=8,619(2,541)$ & $\mathrm{N}=8,050(2,426)$ \\
\hline & & $R^{2}=4.04$ & $R^{2}=18.84$ & $R^{2}=4.04$ & $R^{2}=0.32$ \\
\hline
\end{tabular}




\begin{tabular}{|c|c|c|c|c|c|}
\hline \multirow{2}{*}{$\begin{array}{c}\text { Tax } \\
\text { avoidance } \\
\text { measures }\end{array}$} & \multirow{2}{*}{$\begin{array}{l}\text { Predicte } \\
\text { d sign }\end{array}$} & \multicolumn{2}{|c|}{ Ordinary least squares } & \multicolumn{2}{|c|}{ Fixed effects-panel data } \\
\hline & & Univariate & Multivariate & Univariate & Multivariate \\
\hline \multirow[t]{4}{*}{ Tax Shelter } & - & 0.0054 & -0.0573 & -0.0135 & -0.0153 \\
\hline & & $(3.27)^{* * *}$ & $(-11.13)^{* * *}$ & $(-10.70)^{* * *}$ & $(-5.62) * * *$ \\
\hline & & $\mathrm{N}=8,150$ & $\mathrm{~N}=7,832$ & $\mathrm{~N}=8,150(2,438)$ & $\mathrm{N}=8,095(2,438)$ \\
\hline & & $R^{2}=0.46$ & $R^{2}=19.96$ & $R^{2}=0.46$ & $R^{2}=0.14$ \\
\hline \multirow[t]{4}{*}{ DTAX } & - & 0.0042 & -0.0809 & -0.0368 & -0.0157 \\
\hline & & $(0.21)$ & $(-4.51)^{* * *}$ & $(-3.99) * * *$ & $(-1.55)$ \\
\hline & & $\mathrm{N}=8,223$ & $\mathrm{~N}=7,841$ & $\mathrm{~N}=8,223(2,464)$ & $\mathrm{N}=7,841(2,379)$ \\
\hline & & $R^{2}=0.00$ & $R^{2}=16.20$ & $R^{2}=0.00$ & $R^{2}=2.33$ \\
\hline Audit & - & -0.3184 & -0.1929 & 0.0099 & 0.0084 \\
\hline selection & & $(-22.56)^{* * *}$ & $(-10.68)^{* * *}$ & $(0.86)$ & $(0.66)$ \\
\hline index & & $\mathrm{N}=10,517$ & $\mathrm{~N}=7,841$ & $\mathrm{~N}=10,517(3,109)$ & $\mathrm{N}=8,113(2,436)$ \\
\hline
\end{tabular}

This table reports the coefficient $(\beta)$ of each tax avoidance measure from an individual estimation using this regression model:

$$
\operatorname{CashETR}_{i t}=\alpha+\beta T A M_{i t}+\Sigma \delta_{k} \operatorname{CONTROLS}_{i t}+\Sigma \theta_{l} I N D U S T R Y_{l t}+\Sigma \gamma_{m} Y E A R_{m t}+\varepsilon_{i t}
$$

The dependent variable is CashETR5 which measured by dividing aggregate income tax paid with its corresponding aggregate pre-tax income for five consecutive years. Univariate regressions exclude all control variables while multivariate regressions include Size (measured as the natural log of total assets), Foreign Operations (measured as foreign income scaled by total assets), Leverage, Capital Intensity (measured as total non-current assets scaled by total assets), Inventory Intensity (measured as inventory scaled by total assets), Return on Assets (measured as net profit scaled by total assets), Fiscal Loss (measured as dummy variable coded one if the firm has fiscal loss compensation and 0 otherwise), Changes in Fiscal Loss compensation (measured as changes in fiscal loss carry-forward scaled by lagged total assets), and industry fixed effects using two-digit of Indonesia's standard industry classification developed by the Central Bureau of Statistics of Indonesia (2015) (year and industry fixed effects are excluded in the panel data regressions). Existing tax avoidance measures definitions are provided in Table 1. BTD, Total BTD, Temporary BTD, BTG, and SPREAD are scaled by lagged total assets. Return on Assets, Delta Loss, Foreign Operations, BTD, Temporary BTD, BTG, TSE, and SPREAD are censored to - 1 and 1 . Similarly, all ETRs, Leverage, Capital Intensity, and Inventory Intensity are censored to 0 and 1 . Standard errors are robust and clustered by firms in OLS regressions. T-statistics are displayed in parentheses. $R^{2}$ is stated in percentage $(\%)$. The asterisk $(*)$ indicates the statistical significance of the coefficients at 1 per cent $\left({ }^{* *}\right)$, 5 per cent $(* *)$, and 10 per cent $\left(^{*}\right)$ significance level, respectively.

Furthermore, to infer, in comparison, which existing tax avoidance measure presents more information about firms' medium-run tax burdens, this study assigns the measures which maintain a significant association with CashETR5 in the individual multivariate OLS and Panel Data estimations of equation (4) in a single regression model and allow them to 'compete' (as in Lisowsky et al. (2013) and Efendi et al. (2020)), similar with the estimation method in analysing long-run income tax burdens. Correspondingly, this study estimates the regression model (5) using OLS and fixed effect-panel data regressions after correcting structural multicollinearity problems caused by cross-correlations between BTD-based measures (i.e., Total BTD, Book-tax Gap, SPREAD, Tax Shelter): ${ }^{16}$

$$
\begin{gathered}
\text { CashETR }_{i t}=\alpha+\beta_{1} \text { CashETR }_{i t}+\beta_{2} \text { LagETR }_{i t}+\beta_{3} \text { GAAPETR }_{i t}+\beta_{4} \text { CashflowETR }_{i t}+ \\
\beta_{5} \text { EBITETR }_{i t}+\beta_{6} \text { DeferETR }_{i}+\beta_{7} \text { BTD }_{i t}+\beta_{8} \text { TotalBTD_resid }_{i t}+\beta_{9} \text { TemporaryBTD }_{i t}+ \\
\beta_{10} \text { BTG_resid }_{i t}+\beta_{11} \text { SPREAD_resid }_{i t}+\beta_{12} \text { TSE }_{i t}+\beta_{13} \text { Shelter_resid }_{i t}+\beta_{14} \text { DTAX }_{i t}+ \\
\beta_{15} \text { Arbitrage }_{i t}+\beta_{16} \text { Audit }_{i t}+\Sigma \delta_{k} \text { CONTROLS }_{i t}+\Sigma \theta_{l} \text { INDUSTRY }_{l t}+\Sigma \gamma_{m} \text { YEAR }_{m t}+\varepsilon_{i t}(5)
\end{gathered}
$$

The variables of interest are Cash ETR and fifteen other existing tax avoidance proxies. Thus, the most reliable measure needs to have a statistically significant coefficient with the highest value of $\beta$.

Table 9 reports the results of these estimations. They reveal that using OLS regression,

${ }^{16}$ In correcting multicollinearity problems, this study performs orthogonal transformations (as in Efendi et al., 2020) by, individually, regressing BTD to Total BTD, Book-tax Gap, SPREAD, and Tax Shelter and use the residuals of these regressions as the explanatory variables in estimating model (5). 
Cash ETR, Lagged Cash ETR, Deferred ETR, Temporary BTD, TSE, DTAX, and the tax authority's audit case selection index are statistically-significant (pi.01) to Cash ETR5. Contrarily, employing fixedeffect Panel Data regression, only Cash ETR, Lagged Cash ETR, BTD, and TSE are significant (pio.0l) to Cash ETR5. ${ }^{17}$ Also, the model's explanatory power is substantially reduced compared to that previously estimated by OLS regression suggesting between-firm variations are more prevalent in explaining medium-run income tax burdens relative to variations within an individualfirm. In comparison to other proxies, Lagged Cash ETR retains the most robust ability in predicting medium-run income tax burdens using OLS regression whilst slightly below TSE using Panel Data regression. Overall, the findings justify the evidence on the measure's superior ability in estimating firms' long-run tax burdens.

\section{CONCLUSION AND RECOMMENDATION}

Covid-19 economic crisis provides an epochal opportunity to accelerate tax reforms in curbing corporate tax avoidance through refining the existing bailout conditionality. Accordingly, this study examines and proposes Long-run ETR as a better corporate tax avoidance criterion that should be employed by tax authorities in granting the Covid-19 financial aid programs. Nevertheless, constrained by data availability, computing Long-run ETR may be problematic, particularly for newly registered firms or in the event of mergers and acquisitions. Alternatively, tax authorities can directly analyse firms' Lagged Cash ETR to infer their long-run tax burdens and tax compliance behaviours before the economic downturn. Investigating confidential tax returns of 4,752 largest firms (32,120 firm-years) in Indonesia from 2009 to 2017, this study finds 18.12 percent of total sample firms can retain their Long-run ETR below 10 per cent, which indicates continual tax avoidance activities by these firms during this observation period. Moreover, applying univariate and multivariate OLS and Panel Data regressions, this study reveals, in comparison to other measures, Lagged Cash ETR presents the most consistent ability in predicting long-run income tax burdens. Thus, this reliable proxy can be adopted in the tax authorities' current bailout verifications.

Additionally, consistent with the OECD's proposal of a unified approach in taxing the digital economy, another study proposed a global minimum effective tax rate as an alternative bailout test yet unable to set the agreed optimum level of the effective tax rate (Laffitte et al., 2020). In this framework, the mean Lagged Cash ETR can serve as the benchmark of the minimum effective tax rate paid in every country or jurisdiction where the firm operates.

\section{ACKNOWLEDGEMENT}

The author is thankful to both Director of Dissemination, Services, and Public Relations and Director of Tax Data and Information of the Directorate General of Taxes for providing confidential corporate tax return data. The author is also grateful for the motivational support and helpful STATA coding assistance from Dr Robert Czernkowski.

\footnotetext{
${ }^{17}$ This study performs similar Hausman specification tests as in estimating regression model (4) and finds (untabulated) significant correlations between time-invariant factors and the model's residuals. Thus, fixed effect-panel data models are the proper identification choice for the sample.
} 
Table-9: Multivariate regression analysis on reliabilities of existing tax avoidance measures

and the tax authority's internal measure in predicting medium-run tax burdens.

\begin{tabular}{|c|c|c|c|c|c|}
\hline \multirow[t]{2}{*}{ Variable } & \multirow{2}{*}{$\begin{array}{l}\text { Predicted } \\
\text { sign }\end{array}$} & \multicolumn{2}{|c|}{ Ordinary least squares } & \multicolumn{2}{|c|}{ Fixed effects-panel data } \\
\hline & & $\begin{array}{c}\text { Coefficien } \\
t\end{array}$ & $\begin{array}{c}\mathrm{t}- \\
\text { statistic }\end{array}$ & Coefficient & $\begin{array}{c}\mathrm{t}- \\
\text { statisti } \\
\mathrm{c}\end{array}$ \\
\hline Cash ETR & + & 0.1439 & $4.85 * * *$ & 0.0268 & $2.52 * *$ \\
\hline Lagged Cash ETR & + & 0.3949 & $15.72 * * *$ & 0.0689 & $7.53 * * *$ \\
\hline GAAP ETR & + & -0.0141 & -0.53 & 0.0149 & 1.46 \\
\hline Cash flow ETR & + & -0.0053 & -0.69 & & \\
\hline EBIT ETR & + & 0.0238 & 0.90 & & \\
\hline Deferred ETR & + & 0.0669 & $2.66^{* * *}$ & & \\
\hline Book-tax Differences & - & 0.0602 & 1.43 & -0.0813 & $-2.24 * *$ \\
\hline Total BTD_residual & - & 0.0099 & 0.18 & -0.0552 & -1.16 \\
\hline Temporary BTD_residual & - & -0.1171 & $-2.40 * *$ & & \\
\hline Book-tax Gap_residual & - & 0.1532 & 1.60 & 0.2832 & 0.71 \\
\hline SPREAD_residual & - & -0.2442 & -0.81 & -0.0720 & -0.71 \\
\hline Tax Subsidy in Equity & - & -0.1434 & $-3.24 * * *$ & -0.0893 & $-7.13 * * *$ \\
\hline Tax Shelter_residual & - & 0.0146 & 1.40 & -0.0029 & -0.51 \\
\hline DTAX & - & -0.1026 & $-2.36 * *$ & & \\
\hline Audit selection score & - & -0.0965 & $-4.41^{* * *}$ & & \\
\hline Size & \pm & 0.0019 & 1.41 & -0.0049 & -1.62 \\
\hline Foreign & - & -0.9475 & -0.83 & -0.0305 & -0.04 \\
\hline Capital Intensity & - & 0.0146 & 1.00 & 0.0196 & $1.72 *$ \\
\hline Inventory Intensity & - & 0.0146 & 0.85 & -0.0026 & -0.20 \\
\hline Return on Assets & + & -0.0493 & -1.60 & -0.0424 & $-2.03 * *$ \\
\hline Fiscal Loss & - & -0.0092 & -0.74 & 0.0061 & 1.17 \\
\hline Changes in Loss & - & & & -0.2420 & -0.60 \\
\hline Constant & & 0.0765 & $1.79 *$ & 0.3307 & $4.29 * * *$ \\
\hline Industry fixed effect & & Yes & & No & \\
\hline Year fixed effect & & Yes & & No & \\
\hline N (groups) & & 3,038 & & $7,579(2,372)$ & \\
\hline$R^{2}$ & & 47.37 & & 18.77 & \\
\hline
\end{tabular}

This table reports coefficients of this regression model:

CashETR5 $_{i t}=\alpha+\beta_{1}$ CashETRit $+\beta_{2}$ LagETR $_{i t}+\beta_{3}$ GAAPETR $_{i t}+\beta_{4}$ CashflowETR $_{i t}$

$+\beta_{5} E_{B I T E T R}+\beta_{6}$ DeferETR ${ }_{i t}+\beta_{7} B T D_{i t}$

$+\beta_{8}$ TotalBTD resid ${ }_{i t}+\beta_{9}$ TemporaryBT $D_{i t}+\beta_{10} B T G$ resid $_{i t}$

$+\beta_{11} S P R E A D \_$residit $+\beta_{12} T S E_{i t}+\beta_{13}$ Shelter_residit $+\beta_{14} D T A X_{i t}$

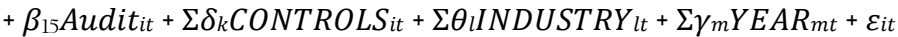

The dependent variable is Cash ETR5 which measured by dividing aggregate income tax paid with its corresponding aggregate pre-tax income for five consecutive years. Independent variables are existing tax avoidance measures which retain significant associations with Cash ETR5 in the individual multivariate OLS and panel data regressions (Table 8). Control variables are Size (measured as the natural log of total assets), Foreign Operations (measured as foreign income scaled by total assets), Leverage, Capital Intensity (measured as total non-current assets scaled by total assets), Inventory Intensity (measured as inventory scaled by total assets), Return on Assets (measured as net profit scaled by total assets), Fiscal Loss (measured as dummy variable coded one if the firm has fiscal loss compensation and 0 otherwise), Changes in Fiscal Loss compensation (measured as changes in fiscal loss carry-forward scaled by lagged total assets (however, this variable is excluded in the OLS regression because of collinearity with other explanatory variables), year and industry fixed effects using two-digit of Indonesia's standard industry classification developed by the Central Bureau of Statistics of Indonesia (2015) (year and industry fixed effects are excluded in the panel data regression). Existing tax avoidance measures definitions are provided in Table 1. Total BTD_resid, BTG_resid, SPREAD_resid, and Shelter_resid are the residuals of regressing BTD to Total BTD, BTG, SPREAD, and Shelter to lessen multicollinearity problems. BTD, Total BTD_resid, BTG_resid, and SPREAD_resid are scaled by lagged total assets. Return on Assets, Delta Loss, Foreign Operations, BTD, BTG, TSE, and SPREAD are censored to - 1 and 1 . Similarly, all ETRs, Leverage, Capital Intensity, and Inventory Intensity are censored to 0 and 1 . Standard errors are robust and clusteredby firms in OLS regression. $R^{2}$ is stated in percentage $(\%)$. The asterisk $\left({ }^{*}\right)$ indicates the statistical significance of the coefficients at 1 per cent $\left({ }^{* *}\right)$, 5 per cent $\left({ }^{* *}\right)$, and 10 per cent $\left({ }^{*}\right)$ significance level, respectively. 


\section{REFERENCES}

Badertscher, B. A., Katz, S. P., \& Rego, S. O. (2013). The separation of ownership and control and corporate tax avoidance. Journal of accounting and Economics, 56(2-3), 228-250.

Bernard, V. L., \& Hayn, C. (1986). Inflation and the distribution of the corporate income tax burden. National Tax Journal, 171-187.

Blouin, J. (2014). Defining and measuring tax planning aggressiveness. National Tax Journal, 67(4), 875.

Blouin, J., \& Tuna, I. (2007). Tax contingencies: Cushioning the blow to earnings. University of Pennsylvania. Retrieved from http://citeseerx.ist.psu.edu/viewdoc/download?doi=10.1.1.169.2476\&rep=repl\&type=pdf

Callihan, D. S. (1994). Corporate effective tax rates: A synthesis of the literature. Journal of accounting literature, 13,1 .

Central Bureau of Statistics of Indonesia. (2015). Indonesia Standard Industrial Classification. In.

Chen, S., Chen, X., Cheng, Q., \& Shevlin, T. (2010). Are family firms more tax aggressive than nonfamily firms? Journal of Financial Economics, 95(1), 41-61.

Cheng, C. A., Huang, H. H., Li, Y., \& Stanfield, J. (2012). The effect of hedge fund activism on corporate tax avoidance. The accounting review, 87(5), 1493-1526.

Collier, R., Pirlot, A., \& Vella, J. (2020). Tax Policy and the COVID-19 Crisis. Intertax, 48(8), 794-804.

Conover, T. L., \& Nichols, N. B. (2000). A further examination of income shifting through transfer pricing considering firm size and/or distress. The International Journal of Accounting, 35(2), 189-211.

Desai, M. A. (2003). The divergence between book income and tax income. Tax policy and the economy, 17, 169-206.

Desai, M. A., \& Dharmapala, D. (2006). Corporate tax avoidance and high-powered incentives. Journal of Financial Economics, 79(1), 145-179.

Desai, M. A., \& Dharmapala, D. (2009). Corporate tax avoidance and firm value. The review of Economics and Statistics, 91(3), 537-546.

Dunbar, A., Higgins, D., Phillips, J., \& Plesko, G. (2010). What do measures of tax aggressiveness measure. Paper presented at the Proceedings of the National Tax Association Annual Conference on Taxation.

Dyreng, S. D., Hanlon, M., \& Maydew, E. L. (2008). Long-run corporate tax avoidance. The accounting review, 83(1), 61-82.

Dyreng, S. D., Hanlon, M., \& Maydew, E. L. (2010). The effects of executives on corporate tax avoidance. The accounting review, 85(4), 1163-1189.

Dyreng, S. D., Hanlon, M., Maydew, E. L., \& Thornock, J. R. (2017). Changes in corporate effective tax rates over the past 25 years. Journal of Financial Economics, 124(3), 441-463.

Efendi, S., Czernkowski, R., Bond, D., \& Morton, E. (2020). Detecting tax avoidance: do existing measures of corporate tax avoidance consistent with the tax authority's assessment? Working paper. Accounting Discipline Group, University of Technology Sydney Business School.

Frank, M. M., Lynch, L. J., \& Rego, S. O. (2009). Tax reporting aggressiveness and its relation to aggressive financial reporting. The accounting review, 84(2), 467-496.

Giuliani, E. (2020). Piketty, Thunberg, or Marx? Shifting ideologies in the COVID-19 bailout 
conditionality debate. Journal of International Business Policy, 1-8.

Gourinchas, P.-O. (2020). Flattening the pandemic and recession curves. Mitigating the COVID Economic Crisis: Act Fast and Do Whatever It Takes, 31.

Griliches, Z., \& Hausman, J. A. (1986). Errors in variables in panel data. Journal of econometrics, 31(1), 93-118.

Gupta, S., \& Newberry, K. (1997). Determinants of the variability in corporate effective tax rates: Evidence from longitudinal data. Journal of accounting and public policy, 16(1), 1-34.

Hanlon, M., \& Heitzman, S. (2010). A review of tax research. Journal of accounting and Economics, $50(2-3), 127-178$.

Hoopes, J. L., Mescall, D., \& Pittman, J. A. (2012). Do IRS audits deter corporate tax avoidance? The accounting review, 87(5), 1603-1639.

Huang, H. H., Lobo, G. J., Wang, C., \& Xie, H. (2016). Customer concentration and corporate tax avoidance. Journal of Banking \& Finance, 72, 184-200.

Institute on Taxation and Economic Policy. (2017a). Fact Sheet: Apple and Tax Avoidance. Retrieved from https://itep.org/fact-sheet-apple-and-tax-avoidance/

Institute on Taxation and Economic Policy. (2017b). Fact Sheet: Nike and Tax Avoidance. Retrieved from https:/itep.org/fact-sheet-nike-and-tax-avoidance/

International Consortium of Investigative Journalist. (2014). Leaked Documents Expose Global Companies' Secret Tax Deals in Luxembourg. Retrieved from https://www.icij.org/investigations/luxembourg-leaks/leaked-documents-expose-globalcompanies-secret-tax-deals-luxembourg/

International Consortium of Investigative Journalist. (2016). Giant Leak of Offshore Financial Records Exposes Global Array of Crime and Corruption. Retrieved from https://www.icij.org/investigations/panama-papers/20160403-panama-papers-globaloverview/

International Consortium of Investigative Journalist. (2017). The 'Paradise Papers' and the Long Twilight Struggle Against Offshore Secrecy. Retrieved from https://www.icij.org/investigations/paradise-papers/paradise-papers-long-twilight-struggleoffshore-secrecy/

International Consortium of Investigative Journalist. (2019). About the Mauritius Leaks Investigation. Retrieved from https://www.icij.org/investigations/mauritius-leaks/about-themauritius-leaks-investigation/

Kinney, M. R., \& Swanson, E. P. (1993). The accuracy and adequacy of tax data in Compustat. The Journal of the American Taxation Association, 15(1), 121.

Klassen, K. J., \& Laplante, S. K. (2012). The effect of foreign reinvestment and financial reporting incentives on cross-jurisdictional income shifting. Contemporary Accounting Research, 29(3), 928-955.

Kubick, T. R., \& Masli, A. N. (2016). Firm-level tournament incentives and corporate tax aggressiveness. Journal of accounting and public policy, 35(1), 66-83.

Laffitte, S., Martin, J., Parenti, M., Souillard, B., \& Toubal, F. (2020). International Corporate Taxation after Covid-19: Minimum Taxation as the New Normal. CEPII Policy Briefs(30).

Lind, Y. (2020). Sweden and Denmark Incorporate Anti-Tax-Avoidance Rules into Very Different COVID-19 Responses. Tax Notes International, 98(10), 1127-1133.

Lisowsky, P. (2010). Seeking shelter: Empirically modeling tax shelters using financial statement 
information. The accounting review, 85(5), 1693-1720.

Lisowsky, P., Robinson, L., \& Schmidt, A. (2013). Do publicly disclosed tax reserves tell us about privately disclosed tax shelter activity? Journal of Accounting Research, 51(3), 583-629.

Manzon Jr, G. B., \& Plesko, G. A. (2001). The relation between financial and tax reporting measures of income. Tax L. Rev., 55, 175.

McGuire, S. T., Omer, T. C., \& Wang, D. (2012). Tax avoidance: Does tax-specific industry expertise make a difference? The accounting review, 87(3), 975-1003.

Mills, L. F. (1998). Book-tax differences and Internal Revenue Service adjustments. Journal of Accounting Research, 36(2), 343-356.

Omer, T., Molloy, K., \& Ziebart, D. (1991). Using financial statement information in the measurement of effective corporate tax rates. Journal of the american taxation Association, $13(1), 57-72$.

Organisation for Economic Co-operation and Development. (2017). Model Tax Convention on Income and on Capital: Condensed Version 2017.

Oyelere, P. B., \& Emmanuel, C. R. (1998). International transfer pricing and income shifting: Evidence from the UK. European Accounting Review, 7(4), 623-635.

Plesko, G. A. (1999). Book-tax differences and the measurement of corporate income. Paper presented at the Proceedings. Annual Conference on Taxation and Minutes of the Annual Meeting of the National Tax Association.

Plesko, G. A. (2003). An evaluation of alternative measures of corporate tax rates. Journal of accounting and Economics, 35(2), 201-226.

Porcano, T. (1986). Corporate tax rates: Progressive, proportional, or regressive. Journal of the american taxation Association, 7(2), 17-31.

Rego, S. O. (2003). Tax-avoidance activities of US multinational corporations. Contemporary Accounting Research, 20(4), 805-833.

Rego, S. O., \& Wilson, R. (2012). Equity risk incentives and corporate tax aggressiveness. Journal of Accounting Research, 50(3), 775-810.

Richardson, G., Taylor, G., \& Lanis, R. (2013). Determinants of transfer pricing aggressiveness: Empirical evidence from Australian firms. Journal of Contemporary Accounting \& Economics, $9(2), 136-150$.

Shevlin, T. (1987). Taxes and off-balance-sheet financing: research and development limited partnerships. Accounting Review, 480-509.

Shevlin, T. (1990). Estimating corporate marginal tax rates with asymmetric tax treatment of gains and losses. Journal of the american taxation Association, 11(2), 51-67.

Spooner, G. M. (1986). Effective tax rates from financial statements. National Tax Journal, 39(3), 293-306.

Tax Justice Network. (2020). Tax Responsible Rules for Corona Bailouts. Retrieved from https://www.taxjustice.net/wp-content/uploads/2020/04/Tax-responsible-rules-for-CoronaBailouts-Tax-Justice-Network-April-2020.pdf

Taylor, G., Richardson, G., \& Lanis, R. (2015). Multinationality, tax havens, intangible assets, and transfer pricing aggressiveness: An empirical analysis. Journal of International Accounting Research, 14(1), 25-57.

U.S. General Accounting Office. (1990). 1987 Company Effective Tax Rates Higher than in Prior 
Years. Retrieved from https://www.gao.gov/assets/150/149014.pdf

United Nations Conference on Trade and Development. (2015). World investment report: reforming international investment governance. Retrieved from https://unctad.org/en/PublicationsLibrary/wir2015_en.pdf

Wilkie, P. J. (1992). Empirical evidence of implicit taxes in the corporate sector. The Journal of the American Taxation Association, 14(1), 97.

Wilkie, P. J., \& Limberg, S. T. (1993). Measuring explicit tax (dis) advantage for corporate taxpayers: An alternative to average effective tax rates. The Journal of the American Taxation Association, 15(1), 46.

Wilson, R. J. (2009). An examination of corporate tax shelter participants. The accounting review, 84(3), 969-999.

Zimmerman, J. L. (1983). Taxes and firm size. Journal of accounting and Economics, 5, 119-149. 